\title{
Influence of Seascape on Coastal Lagoon Fisheries: the Role of Habitat Mosaic in the Venice Lagoon
}

\author{
Luca Scapin $^{1}$ - Matteo Zucchetta ${ }^{2} \cdot$ Fabio Pranovi $^{1} \cdot$ Piero Franzoi $^{1}$
}

Received: 26 November 2020 / Revised: 26 May 2021 / Accepted: 19 July 2021 / Published online: 23 September 2021

(c) The Author(s) 2021

\begin{abstract}
Fisheries are a staple human activity supported by coastal lagoons. Together with water quality and trophic status, lagoon morphology is acknowledged as one of the main ecological drivers of fishery yields; however, the role of lagoon seascape structure is still poorly understood. This paper investigates how morphological variables, habitat distribution and seascape diversity and complexity affect yields of artisanal fishery performed with fyke nets in the Venice Lagoon (northern Adriatic Sea, Italy). Two spatial scales were considered in the analysis, with water quality parameters (temperature, salinity, dissolved oxygen, turbidity, water residence times, N, P and chlorophyll-a concentrations) being measured at a fine, fyke-net scale and morphological (average bottom elevation and sediment grain size) and habitat features (habitat proportion, diversity and complexity) being measured at a broader, seascape scale. Generalised linear mixed models were employed to model 8 years of nekton and green crab catches, disentangling the role of broad-scale morphology and seascape from that of fine-scale water quality. Broad-scale variables clearly influenced fishery target species. Among them, lagoon residents were associated with specific morphological and habitat characteristics, while marine migrants showed a stronger link with overall habitat diversity and complexity. This evidence emphasises how artisanal fishery in the Venice Lagoon relies on the conservation of morphological and habitat heterogeneity. Moreover, it highlights how habitat restoration performed at the seascape level should also be taken into account, in addition to controlling hydrology and water quality, when managing fishery resources in coastal lagoons.
\end{abstract}

Keywords Artisanal fishery $\cdot$ Transitional waters $\cdot$ Fyke nets $\cdot$ Landscape $\cdot$ Morphology $\cdot$ Management

\section{Introduction}

Transitional waters (estuaries and coastal lagoons) are highly productive ecosystems that support a variety of fishery activities, most of which are practised at small-scale (Granzotto et al. 2001; Crespi 2002; Gomez et al. 2006; Pérez-Ruzafa and Marcos 2012). In Mediterranean coastal lagoons, fixed gears and barriers at sea inlets are some of the most widely

Communicated by Charles Simenstad

Luca Scapin

luca.scapin@unive.it

1 Dipartimento Di Scienze Ambientali, Informatica E Statistica (DAIS), Università Ca' Foscari, Via Torino 155, 30170 Mestre, Venice, Italy

2 Istituto Di Scienze Polari, Consiglio Nazionale Delle Ricerche (CNR), Via Torino 155, 30170 Mestre, Venice, Italy used techniques (Cataudella et al. 2015). They exploit faunal movements either within the lagoon basin or between the lagoon and the adjacent marine and freshwater ecosystems, and target a variety of species including fish, decapods and cephalopods (Cataudella and Ferlin 1984; Quignard 1984; Ardizzone et al. 1988; Chauvet 1988; Pérez-Ruzafa and Marcos 2012; Pranovi et al. 2013; Zucchetta et al. 2016). Nekton assemblages found in lagoons represented for millennia one of the major sources of livelihood and income for local populations, making fishery a primary ecosystem service provided by the high productivity and resilience of transitional waters (Pranovi et al. 2013; Cataudella et al. 2015; Rova et al. 2015). Fishery productivity in these ecosystems has been maintained by means of a variety of hydraulic and morphological interventions, which evolved through time along with the development of fishing techniques themselves. Lagoon fisheries therefore not only play an important role in food provisioning for local communities, but also indirectly contribute to the conservation of physical and biological 
diversity (Pérez-Ruzafa and Marcos 2012; Cataudella et al. 2015). In the Venice Lagoon, the historical preservation of shallow water morphologies and management of hydraulic patterns fostered the development of a particularly complex and diversified fishery, which is still one of the most important in the Mediterranean basin in terms of both fishing effort and yields (Provincia di Venezia 2000; Provincia di Venezia 2009; Provincia di Venezia 2015). The regulating and supporting role of morphological heterogeneity in the Venice Lagoon has also motivated the inclusion of habitat restoration practices among the management options for the lagoon basin in more recent years (Curiel et al. 2005; Facca et al. 2014; Feola et al. 2018; Scapin et al. 2019b, c), integrating the traditional approaches based on water quality and hydraulic management (Pérez-Ruzafa et al. 2011; Cataudella et al. 2015).

Spatial and temporal dynamics in physico-chemical parameters play a major role in driving the distribution of nekton in transitional water ecosystems (Elliott and Hemingway 2002; Harrison and Whitfield 2006). Species found within estuaries and coastal lagoons are usually well adapted to such variability; however, temperature, salinity, dissolved oxygen and turbidity levels (among others) can determine physiological and behavioural responses in nekton species, including those that are targeted by local fisheries (Blaber and Blaber 1980; Whitfield et al. 1981; Marshall and Elliott 1998; Maes et al. 2004). For instance, water temperature is known to affect both reproductive investment and fishery catches of grass goby (Zosterisessor ophiocephalus) (Zucchetta et al. 2012; Pranovi et al. 2013), one of the primary fishery resources in the Venice Lagoon (Provincia di Venezia 2009; Provincia di Venezia 2015).

Transitional water ecosystems typically feature a high morphological heterogeneity, resulting in a variety of habitats that are used by nekton species as reproductive, feeding and nursery grounds (Pihl et al. 2002; Pérez-Ruzafa et al. 2007; Whitfield 2017). Morphology significantly influences not only nekton assemblages, but also fishery yields in coastal lagoons. In particular, higher shoreline complexity and amount of shallow-water areas can improve yields by intensifying physico-chemical gradients and nutrient inputs (Pérez-Ruzafa et al. 2007; Pérez-Ruzafa and Marcos 2012). In recent years, seascape ecology emerged as a new approach to effectively investigate the role of habitat mosaic on faunal distribution in coastal ecosystems (Boström et al. 2011). The habitat mosaic approach is successfully contributing in advancing transitional water ecology, by demonstrating the influence of habitat composition (i.e. typology, extent and diversity) and configuration (i.e. spatial arrangement and geometrical complexity) on nekton distribution in estuaries and coastal lagoons (Irlandi and Crawford 1997; Pittman et al. 2007; Staveley et al. 2017; Scapin et al. 2018). Seascape studies have major implications for ecosystem management and biodiversity conservation, tackling ecological issues from a large-scale perspective and taking into account spatial heterogeneity (Mumby 2006; Engelhard et al. 2016; Betzabeth and de los Ángeles 2017). Similarly, understanding how seascape structure determines nekton distribution in transitional water ecosystems may support fishery resource management, for instance by providing a context under which the different options for preserving stocks can be compared (Mizerek et al. 2011), or by identifying areas with the highest potential for recovery from fishing impacts (Stamoulis et al. 2018).

Despite the increasing amount of literature dealing with habitat mosaic influence on commercially important nekton, only very few studies have directly investigated whether seascape attributes influence fishery yields in estuarine and coastal ecosystems (Meynecke et al. 2008; De la TorreCastro et al. 2014). While previous studies emphasised the role of broad morphological categories in influencing fishery yields in coastal lagoons, such as lagoon size, degree of complexity, shallowness (Pérez-Ruzafa et al. 2007), there is a general lack of knowledge about the contribution of habitat mosaic structure in supporting local fisheries. Going beyond the traditional approach of fishery studies, which focused on water quality and productivity as the main drivers of fishery production in transitional waters, this paper takes into account an additional level of complexity and investigates the potential influence of seascape structure on fishery yields in the Venice Lagoon. Following the habitat mosaic approach and including two different spatial scales in the analysis, it disentangles the role of morphology, habitat distribution and habitat mosaic properties from that of water physico-chemical parameters. The outcomes of this study could help improve our understanding of how the conservation and management of coastal lagoon seascapes may benefit local fisheries in the next decades.

\section{Methods}

\section{Venice Lagoon and Study Areas}

The Venice Lagoon is the largest coastal lagoon in the Mediterranean Sea (approximately $550 \mathrm{~km}^{2}$ ). It is connected to the northern Adriatic Sea by three inlets, and experiences microtidal conditions with a tidal range of $\pm 0.50 \mathrm{~m}$ during spring tides (Umgiesser et al. 2004). Most of the lagoon basin is composed of shallow water areas (average lagoon depth $1.2 \mathrm{~m}$ ) that are intersected by a network of channels that could exceed $15 \mathrm{~m}$ of depth (Solidoro et al. 2004; Molinaroli et al. 2007). Environmental conditions in the lagoon are characterised by strong spatial and temporal gradients that are influenced by both natural processes and anthropogenic pressures (Solidoro et al. 2010). The high 
degree of environmental heterogeneity and the geomorphological variability contribute to creating a highly diverse seascape of islands, salt marshes, tidal creeks, mud- and sandflats with or without transient macroalgal beds, seagrass meadows, channels and man-made structures (Franzoi et al. 2010; Solidoro et al. 2010; Scapin et al. 2018).

For the purposes of this study, following the approach of Zucchetta et al. (2016) six broad macroareas were identified in the lagoon based on degree of confinement (Cucco et al. 2009), salinity, sediment characteristics and overall seascape features: Chioggia (CH), Ca' Zane (CZ), Lago dei Teneri (LT), Ponte della Libertà (PL), Poveglia (PO) and San Giuliano (SG) (Fig. 1a).

\section{Fishery Monitoring}

Fyke nets are the most important fishing gear currently used by artisanal fishery in the Venice Lagoon (Granzotto et al. 2001, 2004; Pranovi et al. 2013; Zucchetta et al. 2016). Fyke nets consist of funnel-shaped, unbaited traps arranged in series along barrier nets that are deployed on lagoon shallow bottoms (Provincia di Venezia 2009; Provincia di Venezia 2015). Following Zucchetta et al. (2016), artisanal fishery activities were monitored within the six broad areas previously described. Monitoring took place monthly during the main fishing periods, namely spring (April to June) and autumn (September to November) (Provincia di Venezia 2009). Data from 8 years (2010 to 2017) were collected. Within each broad area, fishermen often change fyke net locations depending on the season, weather and tide conditions and on the specific targets pursued (Provincia di Venezia 2015). As a result, location and extent of actual fishing areas could change among monthly surveys, while always remaining within the boundaries of each broad area as defined in the previous paragraph (Fig. 1b). Hence, also the associated morphological and seascape features could vary over time. This allowed the seascape dataset to better represent the morphological and habitat variability of the lagoon.

For each study area, an average number of 40.9 traps (standard deviation 18.2) were inspected during each sampling occasion. Trap content was inspected on board with the collaboration of professional fishermen, and samples were collected to confirm identification in the laboratory. Catches were identified at species level and weighed $( \pm 1 \mathrm{~g})$. A total of 2574 samples were then included in the analysis.

Nekton fauna (fish, swimming decapods and cephalopods) were considered in the analysis. Also, total catches of green crab Carcinus aestuarii were included in the analysis, due to their importance for artisanal fishery in the Venice Lagoon (Provincia di Venezia 2009; Provincia di Venezia 2015). Green crab was not included among target species since only specific life stages (i.e. moulting specimens and egg-carrying females) have commercial value and are retained by fishermen. In the present work, it was not possible to quantify proportions of commercial stages since selection of individuals is usually performed by fishermen during the days after the capture (Matozzo et al. 2013; Pranovi et al. a

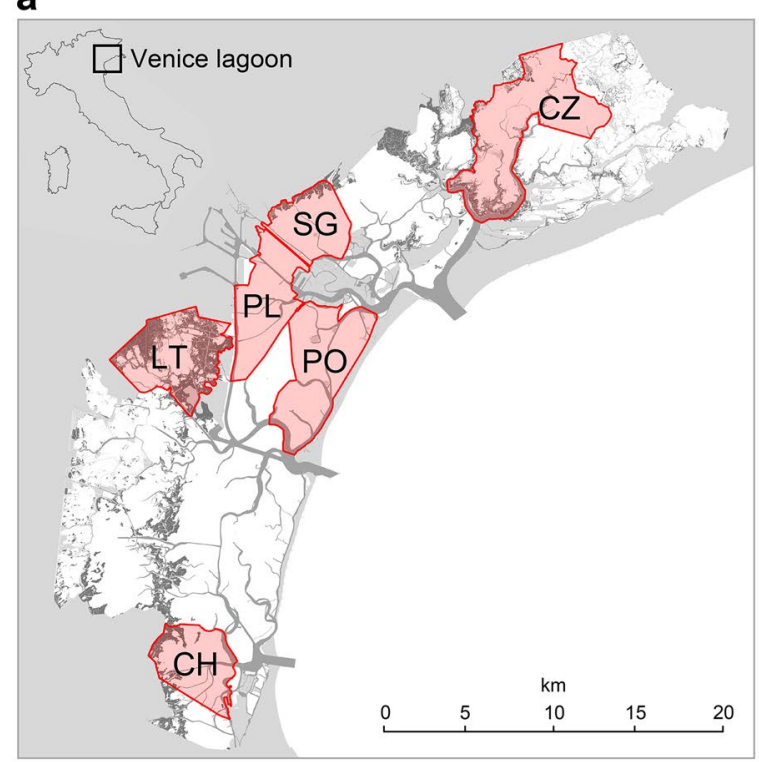

Fig. 1 Six macroareas in the Venice Lagoon (a) and an example of subdivision in fishing areas and spatial scales considered in the study (b). The location of fishing areas (numbered) can change over time due to changes in the position of fishing gears within macroareas (see

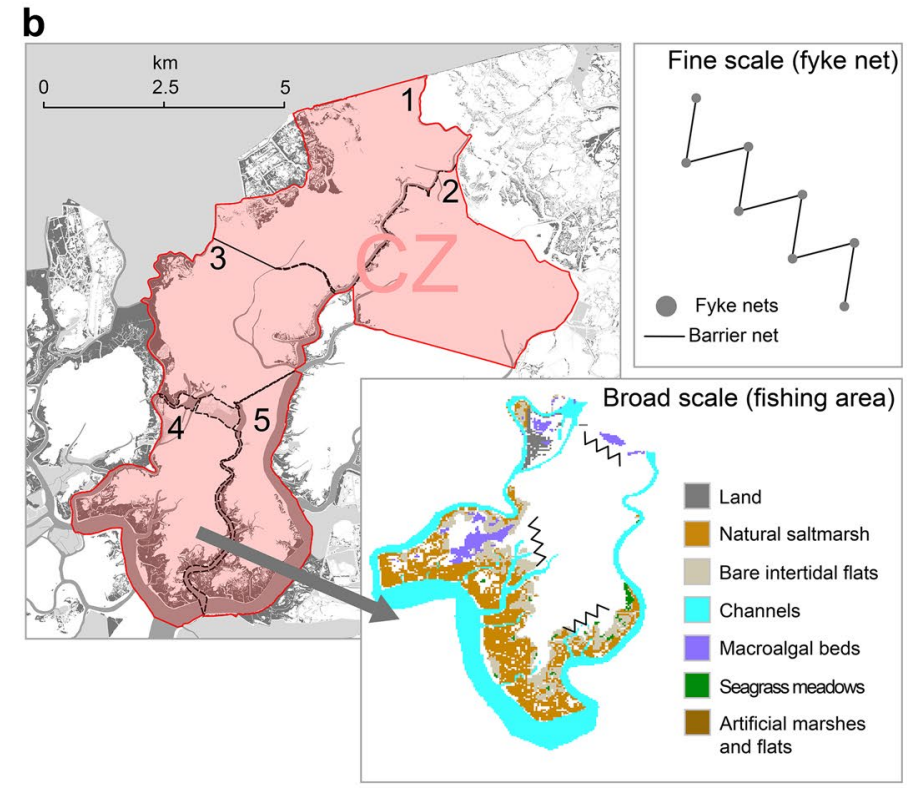

text for details). A stylisation of the fishing gear considered in the study is shown. Habitats quantified at the broad scale are also indicated 
2013). Cumulative biomass per species was then standardised per trap and days of gear deployment, hence expressed as catch per unit effort (cpue). Only for fish species, abundance was also recorded, and the average specimen size was estimated as weight/abundance ratio per species and sample.

\section{Definition and Characterisation of Spatial Scales}

In order to investigate the influence of lagoon morphology and habitat mosaic on fishery yields, data were analysed at a finer fyke-net scale, and at a broader fishing-area scale (see also Fig. 1b). Each spatial scale was characterised with a set of environmental parameters.

Temperature $\left({ }^{\circ} \mathrm{C}\right)$, salinity, dissolved oxygen (saturation $\%$ ) and turbidity (FNU) were recorded in situ during each fyke net survey by means of a multi-parameter probe. In addition, water residence time (days) and total dissolved nitrogen, total dissolved phosphorus and chlorophyll-a concentrations in water $\left(\mu \mathrm{g} \mathrm{L}^{-1}\right)$ were estimated for each fyke net observation using spatial data collected in previous and in regular monitoring programmes (Cucco et al. 2009; Mag. Acque-SAMA, 2013; Regional Agency for Environmental Prevention and Protection (ARPAV), https://www.arpa. veneto.it/dati-ambientali/open-data/idrosfera/acque-ditransizione, URL visited on 27/11/2018). Such set of variables was then employed to characterise the finer scale (see also Appendix 2 Table 3).

Average bottom elevation (metres) and average sediment grain size (\% of sand particles) were calculated for each fishing area and survey month using spatial data collected in previous studies (Mag. Acque, 2002; Mag. Acque-Selc, 2005; Mag. Acque-Thetis, 2005) (see also Appendix 2 Table 3). Six habitat typologies were taken into account: natural salt marsh, lagoon channels, bare intertidal flats, macroalgal beds, seagrass meadows and artificial marshes/ flats. Mainland, islands and man-made fixed structures (e.g. bridges) were also included in the analysis and classified as "no habitat", assuming them to represent physical obstacles for nekton movements. Following Scapin et al. (2018), the temporal variation of some habitats (namely natural salt marshes, creeks, intertidal/subtidal flats, channels and land) was considered negligible within the study period, hence the same land cover map (Mag. Acque, 2002) was used over the entire time span of the analysis. By contrast, temporal variation was taken into account for more dynamic habitats (namely seagrass meadows, macroalgal beds and artificial habitats, the latter created in different occasions during the study period). Cover maps of dynamic habitats were obtained from classification of Landsat-7, Landsat-8 (spatial resolution $30 \mathrm{~m}$ ) and Sentinel-2 (spatial resolution $10 \mathrm{~m}$ ) satellite imagery. Proportion (\% of area occupied) of each habitat was calculated for each fishing area and survey month.
Due to the high collinearity among many commonly-used landscape metrics (McGarigal et al. 2002), habitat diversity and mosaic complexity were chosen as measures of mosaic composition and spatial configuration, respectively (Boström et al. 2011; Scapin et al. 2018). Habitat diversity (Shannon's index calculated on habitat surface) and whole mosaic complexity (landscape shape index) were calculated following McGarigal et al. (2002) for each fishing area and survey month. Morphological properties (average bottom elevation and sediment grain size), habitat distribution and whole mosaic properties (habitat diversity and mosaic complexity) were employed to characterise fishing areas at the broader scale.

\section{Data Analysis}

\section{Preliminary Analysis}

A principal component analysis (PCA) was performed separately on standardised water parameters at the fine scale and on standardised morphological variables and habitat proportions at the broad scale. This served two purposes: (i) to summarise the main spatial and temporal patterns of environmental heterogeneity; (ii) to extract un-correlated information ( $\mathrm{PC}$ axes) from sets of highly correlated variables and include them in a model framework as predictors of fishery yields (Zucchetta et al. 2016; Scapin et al. 2018). Relevant PC axes of both PCAs were selected for the analysis on the basis of proportion of variance explained and by visually inspecting PCA bi-plots, in order to assess which axes could be interpreted as meaningful physico-chemical and morphological patterns (Scapin et al. 2018).

\section{Response Variables}

All nekton species recorded during monitoring activities were categorised according to their importance for artisanal fishery in the Venice Lagoon. Species actively pursued by the fishery were classified as target species; non-target species with a commercial value were classified as accessory species (named incidental in Pranovi et al. 2013); species with no commercial value were classified as discard (Pranovi et al. 2013). As previously described, green crab was not included in fishery categories, to separate the contribution of this benthic species from that of the nekton compartment. See Appendix 1 Table 2 for a complete list of species caught and their allocation in fishery categories.

The influence of lagoon morphology, habitat distribution and whole mosaic properties was investigated on cumulative cpue of each one of the three fishery categories (target, accessory and discard), on green crab cpue, and on cpue and average size of each target species. 


\section{Model Formulation and Selection}

Generalised linear mixed models (GLMMs; Zuur et al. 2009) were fitted separately for each response variable (cpue of fishery categories, target species and green crab and average size of target species). After inspecting the distributions and the mean/variance relationships of response variables (Zuur et al. 2007; Warton 2008; Warton et al. 2014), the tweedie family within the R package glmmTMB (Brooks et al. 2017) was selected as the most appropriate to model both cpues and average sizes.

To take into account the nestedness of sampling design (i.e. a set of fyke net traps sampled within each fishery area), and assuming that the intercept of the regression would change among both traps and fishery areas, a random intercept (with trap nested into fishery area) was specified for all the models. The interaction between survey season and year was included as fixed effect representing the temporal factor.

Following Zucchetta et al. (2016) and Scapin et al. (2018), a hierarchical approach to model selection was followed, so as to hypothesise different contributions of predictors measured at different spatial scales, ultimately disentangling the relative influence of morphology, habitat distribution and mosaic properties quantified at the broad (fishing area) scale from the effect of water parameters measured at the fine (fyke net) scale. Four model categories were included in the analysis, investigating the following hypotheses (Table 1): the response variable is not affected by any of the predictors (null model, category $\mathrm{m} 0$ ); the response variable is affected by temporal factor only (category $\mathrm{m} 1$ ); the response variable responds to temporal factor and water parameters at the fine scale (the latter included progressively as each relevant PC axis; category $\mathrm{m} 2$ ); and the response variable is affected by temporal factor, water parameters at the fine scale and by predictors measured at the broad scale (category $\mathrm{m} 3$ ). To further discern between morphology/habitat distribution and whole habitat mosaic properties, two formulations were introduced in category m3: a first formulation hypothesised that the response variable is affected by temporal factor, water parameters at the fine scale and by morphology and habitat distribution (the latter included as each relevant PC axis); a second formulation hypothesised that the response variable is affected by all the previous predictors, as well as by habitat diversity and mosaic complexity.

Best candidate models were selected by means of the Akaike information criterion corrected for small samples (AICc; Burnham and Anderson 2002), choosing the model with the lower AICc value (Zuur et al. 2009). Models with a difference in AICc lower than 10 were considered undistinguishable (Burnham and Anderson 2002). Each hypothesis formulated was then explored, by verifying if progressive addition of predictors would improve the overall fit of the model (Scapin et al. 2018).

All data analyses were performed in the R environment (R Core Team 2014). Plots were produced using the ggplot 2 package (Wickham 2016).

\section{Results}

\section{Environmental Patterns}

The first three axes of the PCA performed on fine-scale variables were selected as relevant axes summarising physicochemical parameters, since they explained $57.4 \%$ of total variance and highlighted three major environmental gradients (Fig. 2). The first axis identifies a confinement gradient, being positively correlated to salinity and negatively to water residence time and nitrogen concentration. The second axis highlights the seasonal variation in water characteristics, with temperature and chlorophyll-a concentration being negatively correlated to this axis, opposed to dissolved oxygen saturation. Finally, the third axis is associated to a water transparency gradient, with turbidity being negatively correlated to this axis. Despite identifying major environmental

Table 1 Structure of GLMMs employed in this study. The hypothesis and the spatial scale explored by each model formulation are also described. $c$, random intercept, equals $1 \mid$ Area/Fyke net; random structure is the same for all the model formulations

\begin{tabular}{|c|c|c|c|}
\hline $\begin{array}{l}\text { Model } \\
\text { cat- } \\
\text { egory }\end{array}$ & Model structure & Hypothesis & Scale explored \\
\hline $\mathrm{m} 0$ & $Y_{i} \sim c+\varepsilon_{i}$ & Response variable is not influenced by any of the predictors (null model) & None \\
\hline $\mathrm{m} 1$ & $\mathrm{~m} 0+$ season $\times$ year & Response variable is influenced by temporal factor only & None \\
\hline $\mathrm{m} 2{ }_{i}$ & $\mathrm{~m} 1+\mathrm{PC}_{i}$ & $\begin{array}{l}\text { Response variable is influenced by temporal factor and water parameters. The latter are } \\
\text { included progressively as each relevant PC axis } i \text {, hence yielding } i \text { formulations }\end{array}$ & Fine \\
\hline \multirow[t]{2}{*}{$\mathrm{m} 3$} & $\mathrm{~m} 2+\mathrm{PC}_{j}$ & $\begin{array}{l}\text { Response variable is influenced by temporal factor, water parameters as well as by morphol- } \\
\text { ogy and habitat distribution (included as relevant PC axes } j \text { ) }\end{array}$ & Broad \\
\hline & $\mathrm{m} 2+\mathrm{PC}_{j}+\mathrm{DIV}+\mathrm{SHP}$ & $\begin{array}{l}\text { Response variable is influenced by temporal factor, water parameters, morphology/habitat } \\
\text { distribution as well as habitat diversity and whole mosaic complexity }\end{array}$ & \\
\hline
\end{tabular}




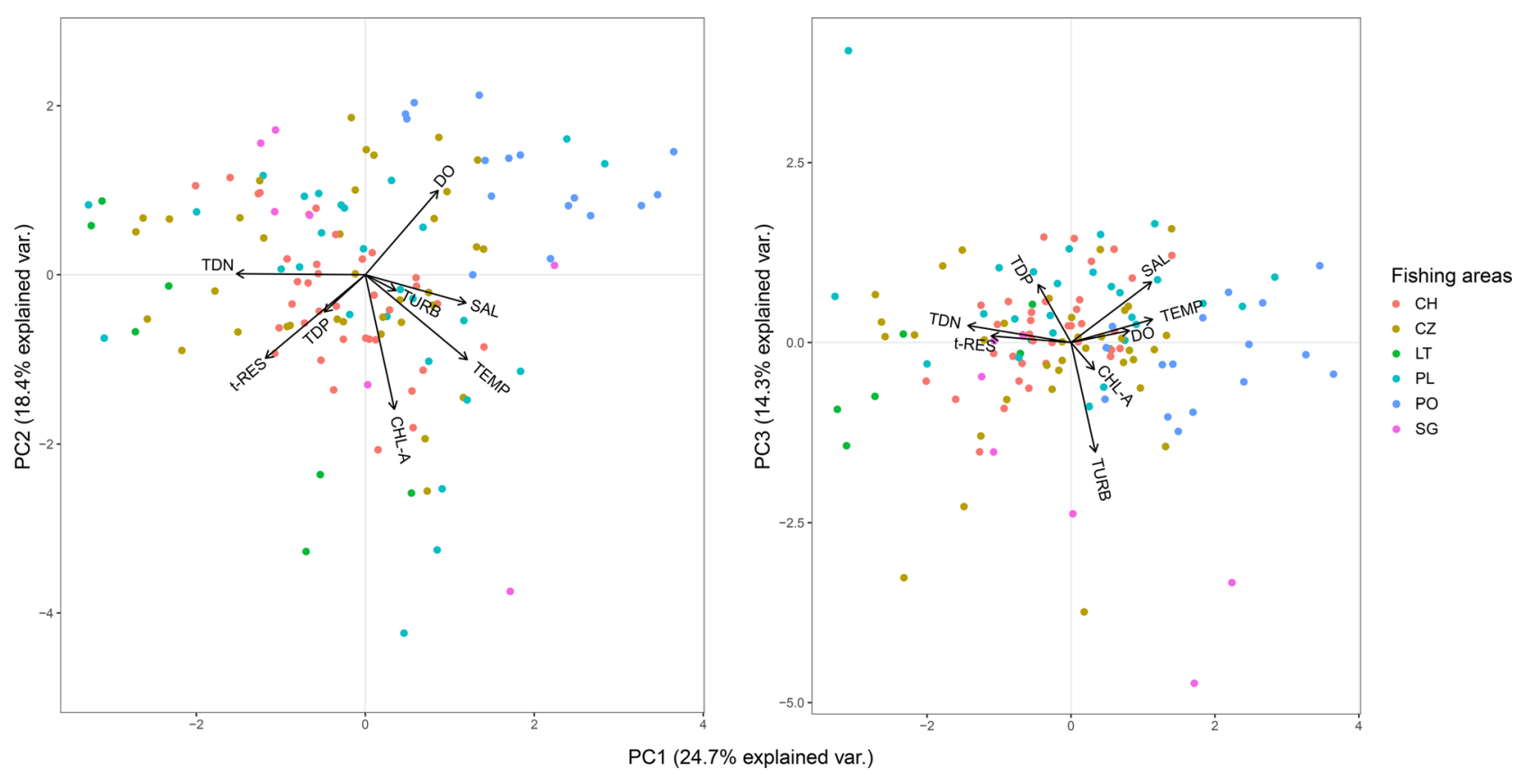

Fig. 2 Biplots of principal component analysis performed on water parameters measured at the fine scale. Variables are abbreviated as follows: TDN, total dissolved nitrogen; t-RES, water residence time;

gradients, the PCA does not allow for a clear separation of observations made within different fishing areas (Fig. 2).

The first two axes of the PCA performed on broad-scale variables were selected as relevant axes summarising morphology and habitat attributes, since they explained $61 \%$ of total variance and allowed for a clear separation among fishing areas (Fig. 3). The first axis is associated to salt marsh and bare intertidal flats, being also positively correlated with bottom elevation and negatively with proportion of macroalgal beds. As a result, it separates fishing areas characterised by higher proportions of salt marsh, intertidal flats and overall shallower bottoms such as $\mathrm{CH}$ and LT from areas dominated by macroalgal beds and subtidal bottoms, such as PL. The second axis highlights a major pattern of seagrass vegetation, with proportion of seagrass meadows and lagoon channels and sand content in sediments being positively correlated with this axis. It then separates fishing areas with sandier bottoms and higher proportion of seagrass meadows and channels, such as PO, CH and PL (only some observations) from areas characterised by lower seagrass coverage and higher proportion of macroalgae and fixed structures, such as PL, CZ (most observations) and SG.

Interpreting the PCAs allowed the use of each PC axis as predictor in the GLMM analysis. Model category m2, investigating the relative influence of fine-scale water parameters, resulted in three alternative formulations, including (in addition to temporal factor): (i) the confinement gradient (first axis of PCA calculated on fine-scale variables);
TDP, total dissolved phosphorus; CHL-A, chlorophyll-a; TEMP, temperature; TURB, turbidity; SAL, salinity; DO, dissolved oxygen

(ii) the confinement gradient and the seasonal variation in water parameters (first and second axes); (iii) the confinement gradient, the seasonal variation in water parameters and the water transparency gradient (first, second and third axes). Conversely, the first and second axes extracted from the PCA calculated on morphology and habitat distribution were both included in the two formulations belonging to model category m3.

\section{Fishery Catch Composition}

Total fishery catches ranged between $704 \pm 31 \mathrm{~g} \mathrm{trap}^{-1} \mathrm{day}^{-1}$ (average \pm SE) in CH and $3222 \pm 245 \mathrm{~g} \mathrm{trap}^{-1} \mathrm{day}^{-1}$ in SG. Green crab accounted for a relevant proportion of total catches in all fishing areas, ranging on average between $35 \%$ in PO and $90 \%$ in SG. Target species accounted for the great majority of nekton catches, while the contribution of both accessory and discard species was the smallest in all the areas. Target nekton catches varied on average between $236 \pm 18 \mathrm{~g} \mathrm{trap}^{-1} \mathrm{day}^{-1}$ in SG and $726 \pm 102 \mathrm{~g}$ trap $^{-1}$ day $^{-1}$ in LT (Fig. 4a). On average, big-scale sand smelt Atherina boyeri and grass goby Zosterisessor ophiocephalus accounted for more than $65 \%$ of target catches in all areas. The proportion of big-scale sand smelt ranged on average between $32 \%$ in SG and $78 \%$ in LT. The contribution of grass goby Zosterisessor ophiocephalus was the largest in PL (39\% of target catches) and the smallest in LT (4\%) (Fig. 4b). 


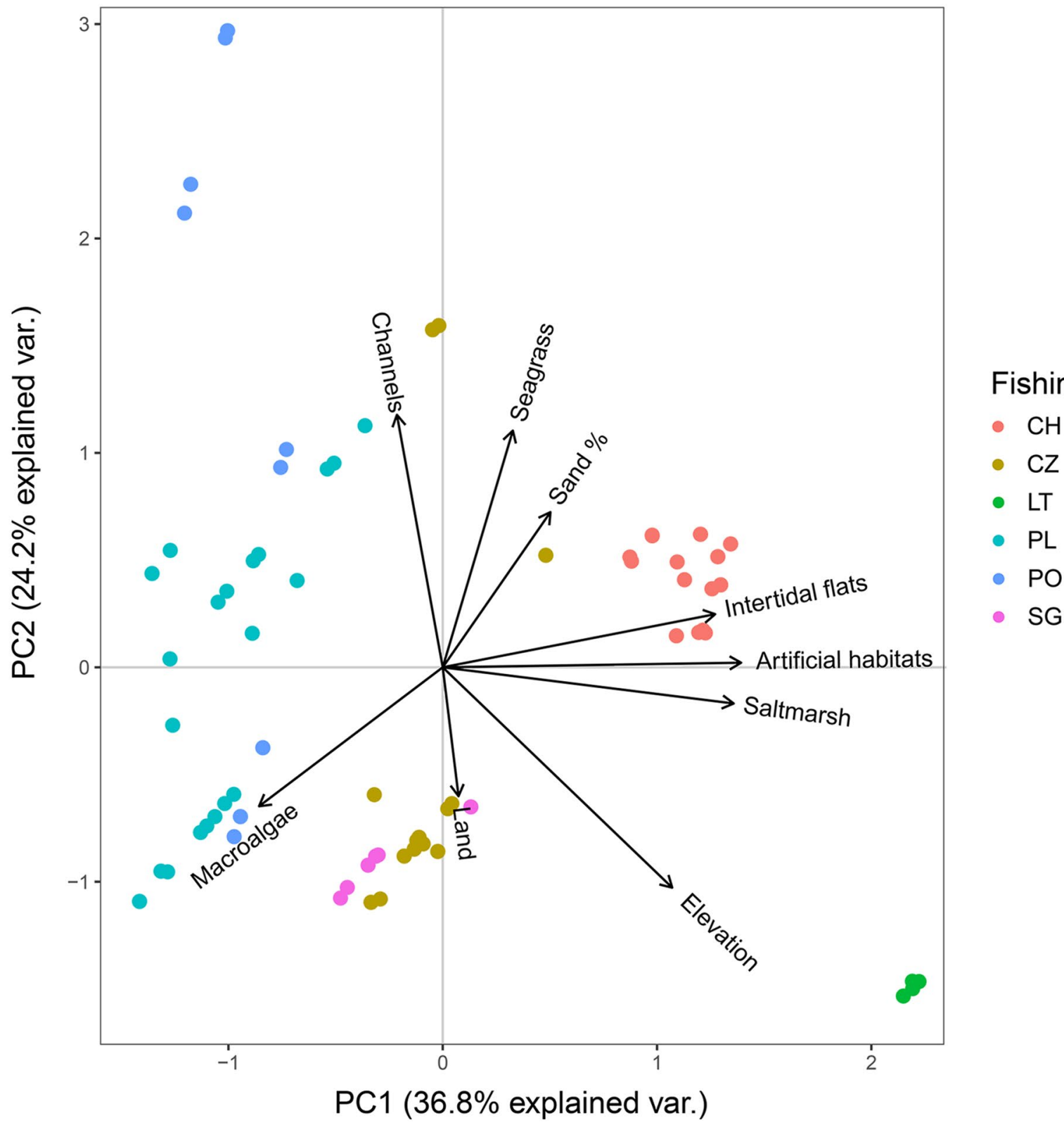

Fig. 3 Biplot of principal component analysis performed on morphological properties and habitat proportion quantified at the broad scale. See text for variable definitions

Some seasonal differences were also found (not illustrated). Three species accounted for more than $90 \%$ of fishery target cpue during spring: big-scale sand smelt Atherina boyeri (49.6\% of target cpue), grass goby Zosterisessor ophiocephalus (30.7\%) and common cuttlefish Sepia officinalis $(10.1 \%)$. Conversely, during autumn an average of five species made up more than $90 \%$ of target cpue: big-scale sand smelt (66.4\%), grass goby (11.4\%), brown shrimp Crangon crangon (5.6\%), lagoon shrimp Palaemon spp. (4.6\%) and European eel Anguilla anguilla (4.3\%). Target species also included European flounder Platichthys flesus, golden grey mullet Chelon auratus, thicklip grey mullet Chelon labrosus, flathead grey mullet Mugil cephalus and Mediterranean sand smelt Atherina hepsetus. The latter three were excluded from the following analyses due to of the low number of observations in the dataset.

\section{Model Selection}

Temporal factor (season and year) was a relevant predictor for all the three fishery categories considered, while water parameters at the fine scale were relevant for accessory and 

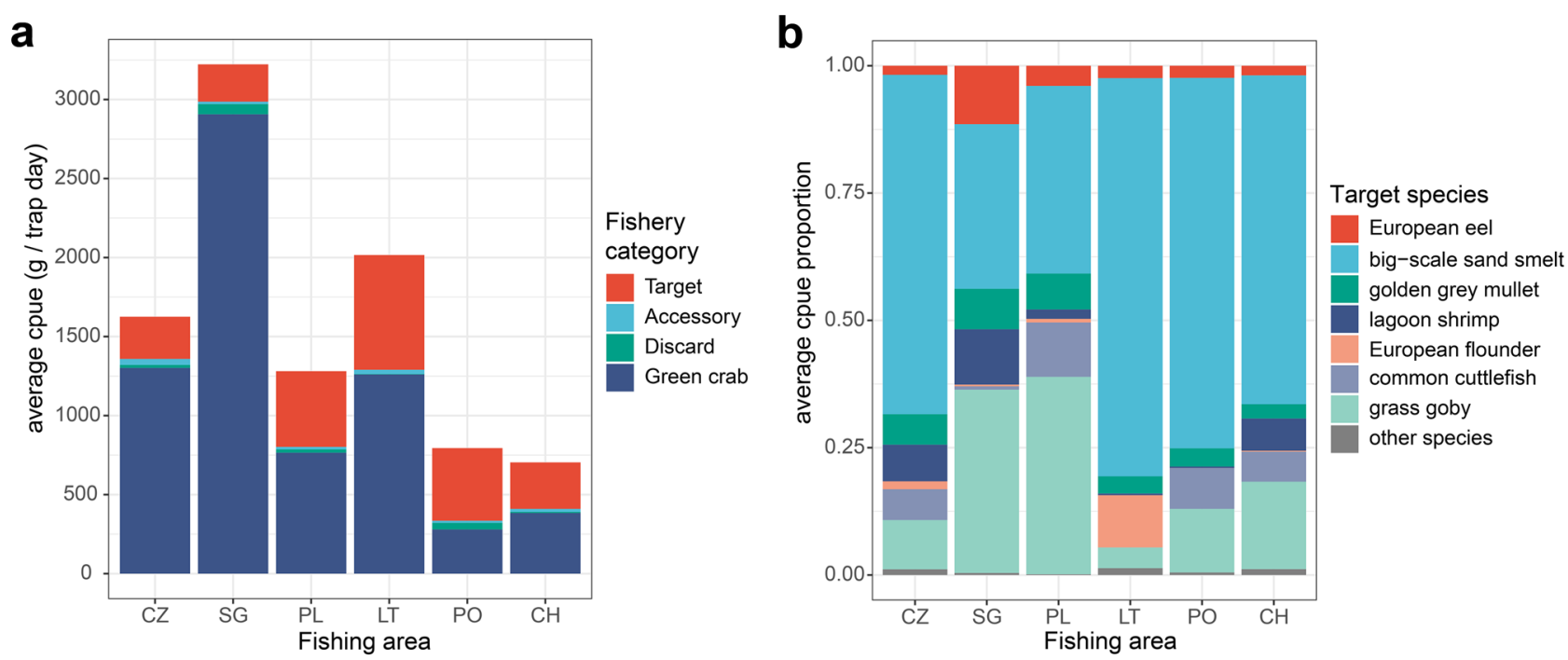

Fig. 4 Total fishery catches (cpue, g trap ${ }^{-1}$ day $^{-1}$ ) (a) and composition of target nekton catches (b) averaged by fishing area. Contributions of fishery categories (including green crab) and target species, respectively are shown

discard species. In particular, accessory species responded to confinement gradient, while discard was influenced by confinement, seasonal pattern in water parameters and transparency. Morphology and seascape properties at the broad scale were also relevant for all the categories. In particular, fishery targets were influenced by both morphology/habitat distribution and whole mosaic properties, while accessory and discard species responded only to mosaic. Green crab cpue responded to transparency at the fine scale and whole mosaic properties at the broad scale, in addition to temporal factor (Fig. 5).

In terms of cpue, all target species except for European eel responded to temporal factor. Furthermore, all target species except for European eel and golden grey mullet were influenced by water parameters at the fine scale. In particular, confinement gradient was a relevant predictor for brown shrimp, lagoon shrimp and grass goby. Seasonal patterns in water parameters were relevant for big-scale sand smelt, brown shrimp, common cuttlefish and grass goby, while transparency was relevant for brown shrimp and European flounder. At the broad scale, morphology/habitat distribution had an influence on big-scale sand smelt, lagoon shrimp and grass goby, while whole mosaic properties were relevant for all the considered species except for European eel, lagoon shrimp and common cuttlefish (Fig. 5).

Regarding average sizes, all species except for European eel and grass goby responded to temporal factor. Confinement gradient was a relevant predictor only for the average size of European flounder, seasonal patterns in water parameters were relevant only for the average size of common cuttlefish, while transparency influenced only the average size of European flounder. While morphology/habitat distribution did not influence the average size of any of the target species, whole mosaic properties influenced the average size of big-scale sand smelt and European flounder (Fig. 5).

\section{Influence of Fine- and Broad-scale Environmental Parameters on Fishery Catches}

Biomass of target species was positively influenced by seagrass distribution and habitat diversity, while being negatively influenced by the proportion of salt marsh and intertidal flats and by mosaic complexity. The biomass of accessory species responded positively to higher salinities and shorter water residence times (i.e. larger cpue values in less confined areas) and to habitat diversity, while being negatively affected by mosaic complexity. Discard biomass was positively affected by higher salinities and shorter residence times, being also negatively associated to seasonal water parameters (i.e. larger cpue during warmer periods) and to the transparency gradient (i.e. larger cpue at higher turbidities). Discard biomass was also positively affected by habitat diversity, and negatively associated to mosaic complexity (Fig. 6).

The inverse confinement gradient had a negative influence on many target species, with biomass of brown shrimp, lagoon shrimp and grass goby and average size of European flounder showing larger values at lower salinity and longer water residence times. In terms of seasonal water parameters, the biomass of big-scale sand smelt showed larger values during warmer periods, while the biomass of brown shrimp, common cuttlefish and grass goby, as well as the average size of common cuttlefish showed larger values 
Fig. 5 Summary of model formulations selected for each response variable via AICc. Predictors included in selected models are highlighted in shades of grey representing temporal factor, water characteristics measured at the fine scale and seascape features quantified at the broad scale

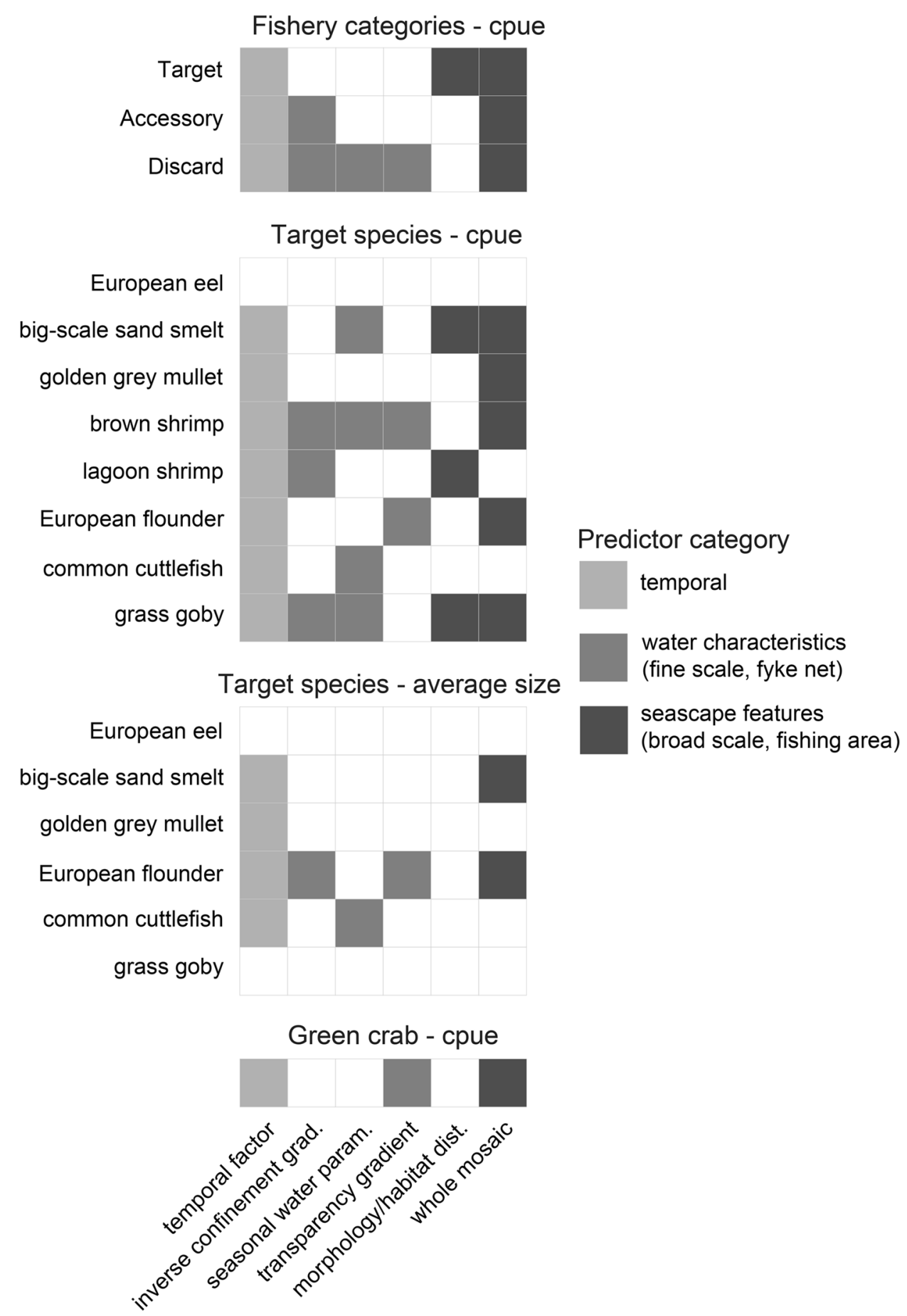

during colder periods. Transparency gradient had a negative influence on the biomass of brown shrimp and European flounder, and on the average size of European flounder (larger values in more turbid conditions), while showing a positive influence on the biomass of green crab (larger values in clearer conditions).

At the broad scale, morphology and habitat distribution had an effect on three lagoon resident species: proportion of salt marsh and bare intertidal flats in the mosaic had a positive effect on the biomass of big-scale sand smelt, while it showed a negative effect on the biomass of lagoon shrimp and grass goby; proportion of seagrass vegetation positively influenced the biomass of big-scale sand smelt, lagoon shrimp and grass goby.

Conversely, the effect of whole mosaic properties was evident on a larger group of species, comprising big-scale sand smelt, golden grey mullet, brown shrimp, European flounder, grass goby and green crab. Habitat diversity had 


\section{Fishery categories}

Target species
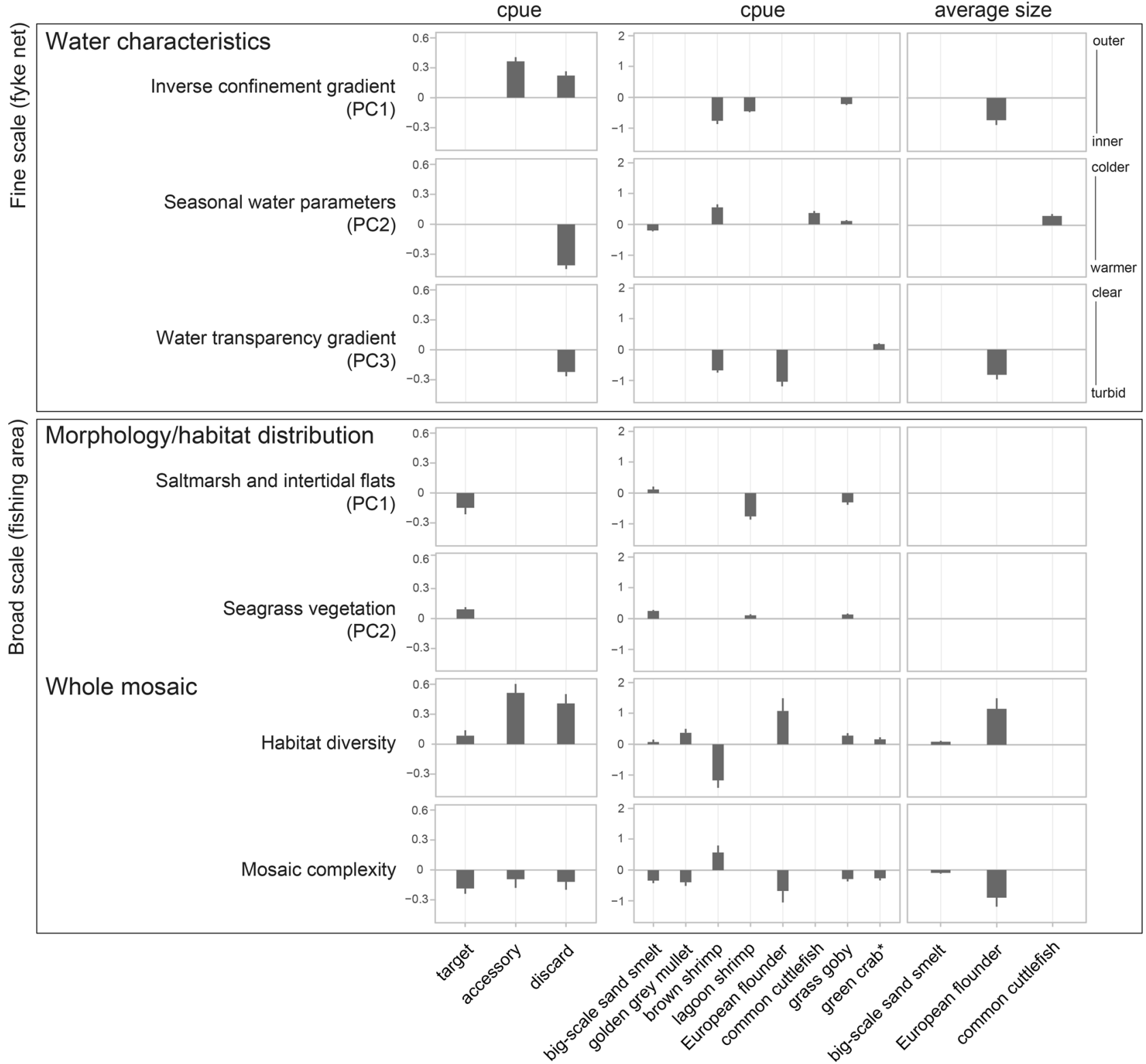

Fig. 6 Standardised coefficients and standard errors of fine- and broad-scale environmental predictors for cpue of fishery categories and cpue and average size of target species, as estimated by selected model formulations. Fine-scale predictors include the first three axes of PCA performed on water parameters; broad-scale predictors include the first two axes of PCA performed on morphology and habitat distribution, and whole mosaic properties. *Green crab Carcinus aestuarii was not classified as target species, but was included in the plot for illustration purposes an overall positive effect, with only the biomass of brown shrimp showing a negative relationship with this parameter. In turn, mosaic complexity showed an overall negative influence, with only the biomass of brown shrimp being positively related to it (Fig. 6).

\section{Discussion}

The hydrological, morphological and ecological complexity characterising coastal lagoons is regarded as one of the key determinants of their productivity, supporting substantial 
fishery and aquaculture industries (Kapetsky and Lasserre 1984; Quignard 1984; Ardizzone et al. 1988; Chauvet 1988; Pérez-Ruzafa and Marcos 2012). The presence and intensity of sea-mainland gradients within lagoon basins and the extent of shallow areas, in particular, are strongly linked to fishing yields. In Mediterranean coastal lagoons, the latter are correlated to the amount of water exchanged between lagoons and the sea, as well as to the intensity of freshwater discharges and to temperature ranges (Pérez-Ruzafa et al. 2007; Cataudella et al. 2015). To a significant extent, such parameters themselves are dependent on morphological traits of lagoon basins (Pérez-Ruzafa et al. 2007; PérezRuzafa and Marcos 2012; Umgiesser et al. 2014). In this light, the present paper takes a step further in investigating the role of lagoon morphology as a determinant of fishery production. Morphological traits measured at the broad scale (4 to $30 \mathrm{~km}^{2}$ ), such as local bottom elevation and sediment grain size, and habitat mosaic properties, such as habitat proportion, diversity and shape complexity indeed influenced both catches and sizes of commercial nekton, in addition to physico-chemical properties measured at the fine scale.

Overall downward trends in fishery yields have been recorded in Mediterranean coastal lagoons over the last decades (Béné 2011; Cataudella et al. 2015). A comparison of fishery yields reported in previous studies (Provincia di Venezia 2000; Granzotto et al. 2001; Libralato et al. 2004; Provincia di Venezia 2009; Provincia di Venezia 2015) with data presented in this paper attests a decreasing trend in catches of various commercial species also in the Venice Lagoon, at least since the 1980s. These include big-scale sand smelt, grass goby, brown shrimp, lagoon shrimp, European eel and European flounder. Variations in environmental conditions due to multiple anthropogenic drivers played a role, including the long-term increase in temperature (Pranovi et al. 2013) and decrease in nutrient inputs (Pastres et al. 2004; Solidoro et al. 2010) recorded in the last decades.

However, also the general degradation of hydrological and morphological features undergone by coastal lagoons must be included among the factors that contributed to the decline of lagoon fisheries. Previous works have reported how the presence of structured habitats and their heterogeneity are crucial in maintaining fishery productivity, and how habitat degradation and loss are among the primary anthropogenic pressures on commercial nekton (Cataudella et al. 2015; Zucchetta et al. 2016; Cavraro et al. 2019). Breber et al. (2008), for instance, demonstrated how past reclamation of shallow water habitats in two European lagoons contributed to the observed decline in local fishery productivity. Similarly, loss in habitat connectivity impaired migration of two commercially relevant mugilid species, subsequently affecting fishery production in coastal lagoons of Tunisia (Romdhane et al. 2019). In the Venice Lagoon, erosion of lagoon seascape structures due to channel dredging, increased navigation and mechanical exploitation of Manila clam Ruditapes philippinarum that occurred in the last decades determined an overall increase in lagoon average depth and the loss of morphological heterogeneity (Sarretta et al. 2010; Solidoro et al. 2010). Some critical habitats for nekton species including salt marsh, intertidal and subtidal flats and seagrass meadows were particularly impacted (Franco et al. 2009; Thetis S.p.A. (Ed.) 2010; Zucchetta et al. 2016; Cavraro et al. 2017; Scapin et al. 2018). The intensive harvesting of manila clam had an additional effect on artisanal fishery. Not only did it affect sediment stability and dynamics, but it also determined a relevant shift in fishing targets and practices among fishermen in the Venice Lagoon. Such shift towards manila clam as a very abundant, readily available and more marketable product contributed to the observed decrease of artisanal fishing effort and to the subsequent decrease of fishery production during the late 1980s and 1990s (Provincia di Venezia 2000; Libralato et al. 2004; Provincia di Venezia 2009).

In this paper, both accessory and discard species among fishery categories appeared to be more influenced by water characteristics at the fine scale. Conversely, target species showed the more evident association with morphological and habitat mosaic properties at the broad scale. Target species that exhibited a clear link to morphological properties (bottom elevation and sediment grain size) and specific habitats (proportion of natural and artificial salt marsh and intertidal flats, seagrass meadows, macroalgal beds, lagoon channels) were essentially lagoon residents (Franco et al. 2008; Potter et al. 2013; Scapin et al. 2019a) (see Appendix 1 Table 2). In the Venice Lagoon as well as in other estuarine ecosystems, these species spend most of their life cycle in transitional waters, often showing morphological, behavioural and reproductive adaptations to particular habitats (Malavasi et al. 2005; Franzoi et al. 2010; Scapin et al. 2018; Kara and Quignard 2019).

Artisanal fishery in the Venice Lagoon shares some common features with other small-scale fisheries in Mediterranean coastal lagoons, including the widespread use of passive gears employed by local fishermen by means of small ( $<12$-m-long) boats (Pranovi et al. 2013). Nevertheless, it retains some relevant peculiarities that differentiate it from the others. Many lagoon fisheries rely on fixed structures, usually located at the sea inlet (e.g. lavorieri, bordigues and encañizadas in Italy, France and Spain respectively), mainly targeting highly motile, migrant nekton (mainly Mugilidae, Sparidae, Anguillidae and Moronidae) (Cataudella and Ferlin 1984; Kapetsky and Lasserre 1984; Ardizzone et al. 1988; Pérez-Ruzafa and Marcos 2012). Conversely, fishery performed with fyke nets in the Venice Lagoon relies to a larger extent on smaller-sized nektonic resident species such as big-scale sand smelt and grass goby as well as on green crab (Pranovi et al. 2013; Provincia di Venezia 2015). Such 
resident species are strongly linked to the morphological and habitat features that characterise the Venice Lagoon. Grass goby is usually associated to seagrass vegetation, whose root system help in stabilising burrow nests dug into soft sediments for wintering, summering and reproduction (Gandolfi et al. 1991; Malavasi et al. 2005; Franco et al. 2012). Big-scale sand smelt, despite being ubiquitous in the Venice Lagoon (Franco et al. 2006; Franzoi et al. 2010), select shallow-water structured habitats including macroalgal and seagrass beds as spawning grounds, to which they exhibit a certain degree of site fidelity (Henderson et al. 1988; Koutrakis et al. 2004; Kara and Quignard 2019). Fishery in the Venice Lagoon (and northern Adriatic lagoons nearby, e.g. Grado-Marano Lagoon) therefore relies to a larger extent, compared to those practised in other Mediterranean lagoons, on the presence of vast portions of fine-sediment, intertidal and subtidal shallow areas representing the main reproductive, feeding and shelter habitats for the major commercial targets.

This work highlighted that whole mosaic properties (habitat diversity and mosaic shape complexity) influenced to a higher extent marine migrant target species compared to resident ones. Most of these species share marine reproduction and spawning strategies, and enter the Venice Lagoon and other transitional water ecosystems either to exploit nursery habitats as juveniles (marine estuarine-dependent), for trophic purposes (marine estuarine-opportunists) or during migrations between marine and freshwater habitats (catadromous) (Franzoi et al. 2010; Scapin et al. 2019a). Compared to resident species, marine migrants are highly motile, and many of them exhibit substantial changes in habitat preference during their life cycle, while being subjected to ontogenic shifts in morphology and diet preferences (Pita et al. 2002; Tancioni et al. 2003; Georgalas et al. 2007; Andolina et al. 2020). Moreover, most species perform movements among habitats on a daily basis by following tidal cycles, seeking shelter and forage (Irlandi and Crawford 1997; Hampel et al. 2003; Rountree and Able 2007). This paper shows an overall positive response of target species to habitat diversity, suggesting that these species would benefit from the presence of more heterogeneous lagoon seascapes. For instance golden grey mullet $C$. auratus and European flounder P. flesus, which are traditionally targeted by transitional water fisheries in the Mediterranean, exploit the estuarine seascape during juvenile and sub-adult stages, performing movements among habitats while undergoing ontogenic diet shifts (Franco et al. 2010; Zucchetta et al. 2010; Amorim et al. 2018).

The results of the present paper therefore emphasise the critical importance of multi-functional shallow water habitats that are used as feeding, shelter and reproductive grounds by resident nekton in the Venice Lagoon and similar transitional water bodies. In addition, they highlight how a certain degree of habitat diversity is needed by sub-adult individuals of marine migrant species that significantly contribute to sustain lagoon fisheries.

Among commercial species considered in this analysis, common cuttlefish Sepia officinalis showed a clear response only to temporal variability (i.e. temporal factor and seasonal patterns in water parameters). This marine migrant species is regularly found in the Venice Lagoon (Provincia di Venezia 2009; Provincia di Venezia 2015). In contrast to most marine migrant species considered in this work, which perform migrations to exploit shallow-water nursery and feeding grounds, common cuttlefish penetrate transitional waters mainly for reproductive reasons. In the Venice Lagoon this species often gathers in deeper and more dynamic lagoon channels, possibly being attracted by a variety of structured habitats that are used for spawning (e.g. rocky substrata, subtidal seagrass meadows and artificial structures) (Guerra 2006; Guerra et al. 2016; Grati et al. 2018). As a result, cuttlefish is traditionally pursued with a wide range of fishing gears deployed in deeper waters, including trawl nets, gill nets and traps in addition to fyke nets (Provincia di Venezia 2015). This may partially explain the lack of response to both spatial gradients (i.e. confinement and transparency) and seascape parameters of fyke net catches in shallow waters.

Similarly, also green crab Carcinus aestuarii showed an overall weak response to shallow water seascape structure; this is probably due to the benthic habits and relatively low motility that differentiate this species from the nektonic taxa considered in this work. Despite that, in the Venice Lagoon green crab represent the most important taxon in fyke net catches in terms of total biomass, as well as one of the most valuable fishery resources during certain life stages (Provincia di Venezia 2000; Provincia di Venezia 2009; Provincia di Venezia 2015). In Northern Adriatic coastal lagoons, only moulting individuals and ripe females are indeed retained and marketed, after a temporary relaying phase following catch and selection (Matozzo et al. 2013; Pranovi et al. 2013).

Size of commercial species is of particular importance for fisheries, since larger specimens are usually more valuable. Body condition measures in fish are commonly used as indicators of ecosystem health in transitional waters, being employed to evaluate productivity and anthropogenic pressures among habitats (Amara et al. 2007; Piazza and La Peyre 2010; Cavraro et al. 2019). This work emphasises that fish individual weight in transitional waters can be influenced by morphology and seascape structure, these being potential drivers of fish individual health. This confirms findings of previous authors, who pointed out that human alterations to morphology in coastal lagoons impact negatively on individual fish condition (Cavraro et al. 2019). This suggests that preserving and restoring habitat mosaics in 
transitional water ecosystems could benefit local fisheries not only in terms of overall yields, but also in terms of sizes of individual catches.

Ecological restoration is considered a strategic approach to revert loss of biodiversity and degradation of ecosystem functionality (Suding 2011; Menz et al. 2013; Perring et al. 2015). It is also regarded as a way to contribute towards preserving and enhancing ecosystem services, including provision of natural resources such as food (Jones 2013; Perring et al. 2015). Restoration of estuaries and coastal lagoons is particularly critical, since they support strategic fishery and aquaculture industries, while being at the same time subjected to high levels of anthropogenic pressures (Béné 2011; Pérez-Ruzafa and Marcos 2012). Pérez-Ruzafa et al. (2007; 2012) previously pointed out the importance of features such as lagoon size, shallowness, coastline development and degree of sea-lagoon connectivity, emphasising that resource management in coastal lagoons aims in particular at maintaining or modifying such morphological traits in order to maximise productivity. In this light, this paper not only confirms the relevance of overall morphological features for fishery yields, but also introduces habitat composition and diversity as additional, primary factors affecting fishery productivity. By highlighting how morphological and seascape features can positively affect fishery yields, this paper suggests that conservation and restoration of morphological traits including habitats and seascape complexity and diversity can contribute to the management of lagoon fishery resources in the future.

Previous studies reported how habitat restoration would benefit fishery productivity in transitional waters. Restoration measures aiming at increasing marsh edge and overall complexity in salt marsh seascapes, for instance, could support the standing crop of commercial species associated with structured habitats (Rozas et al. 2005). Also restoring habitat connectivity would benefit fishery species, as pointed out by Mizerek et al (2011) in patchy seagrass seascapes. Moreover, large-scale restoration of lagoon and estuarine hydraulic regimes may substantially enhance both recruitment and commercial yields of migrant nekton species by increasing tidal exchanges and sea-lagoon connectivity (Mohapatra et al. 2007; Tsihrintzis et al. 2007; Reese et al. 2008).

This paper emphasises how management actions towards the preservation of fishery resources in coastal lagoons should be taken at the seascape level. The preservation of gradients in water characteristics, including salinity, turbidity and trophic status, should therefore be accompanied by the conservation and restoration of whole habitat mosaics. A seascape approach in coastal lagoon management could benefit local fisheries not only directly, by enhancing habitat availability and quality for target species as demonstrated here, but also indirectly, by tackling ecosystem-scale, longterm changes that could negatively affect fishery productivity (e.g. variations in temperature and trophic status). Coastal lagoons are inherently dynamic ecosystems, and their provisional services have always been strongly linked to human intervention (Béné 2011; Cataudella et al. 2015). In order to preserve lagoons' capability to support populations of species of commercial interest, in the next years management should focus on restoring not only habitat functionality, but also connectivity among habitats and the overall mosaic heterogeneity.

Acknowledgements We thank Riccardo Fiorin and Federico Riccato (Laguna Project s.n.c.) for carrying out the fieldwork. We are grateful also to the fishermen Ivan Bognolo, Umberto Costantini and Mario Salvagno for their collaboration in fieldwork activities.

Funding Open access funding provided by Università Ca' Foscari Venezia within the CRUI-CARE Agreement. This study has been partially funded by the Italian Ministry of Universities and Research (PRIN grants 2009W2395), by Corila (Consorzio Ricerche Lagunari) and by the local water authority Provveditorato Interregionale alle OO. PP. del Veneto-Trentino Alto Adige - Friuli Venezia Giulia.

\section{Declarations}

Conflict of Interest The authors declare no competing interests.

Open Access This article is licensed under a Creative Commons Attribution 4.0 International License, which permits use, sharing, adaptation, distribution and reproduction in any medium or format, as long as you give appropriate credit to the original author(s) and the source, provide a link to the Creative Commons licence, and indicate if changes were made. The images or other third party material in this article are included in the article's Creative Commons licence, unless indicated otherwise in a credit line to the material. If material is not included in the article's Creative Commons licence and your intended use is not permitted by statutory regulation or exceeds the permitted use, you will need to obtain permission directly from the copyright holder. To view a copy of this licence, visit http://creativecommons.org/licenses/by/4.0/. 


\section{Appendix 1}

Table 2 Average cpue and standard deviation of species recorded in fyke nets during artisanal fishery surveys in the Venice Lagoon. Nekton species are allocated in categories according to their impor- tance for artisanal fishery (green crab Carcinus aestuarii was treated separately). Estuarine use categories are also reported (Scapin et al. 2019a)

\begin{tabular}{|c|c|c|c|c|c|}
\hline Species & Common name & Fishery category & $\begin{array}{l}\text { Estuarine use } \\
\text { category }\end{array}$ & $\begin{array}{l}\text { Average cpue (g } \\
\text { trap }^{-1} \text { day }^{-1} \text { ) }\end{array}$ & sd \\
\hline Atherina boyeri & Big-scale sand smelt & Target & ES & 220.88 & 117.93 \\
\hline Zosterisessor ophiocephalus & Grass goby & Target & ES & 76.74 & 35.98 \\
\hline Sepia officinalis & Common cuttlefish & Target & ME-O & 24.18 & 13.26 \\
\hline Chelon auratus & Golden grey mullet & Target & ME-D & 18.16 & 13.28 \\
\hline Palaemon spp. & Lagoon shrimp & Target & ES & 14.74 & 9.57 \\
\hline Anguilla anguilla & European eel & Target & $\mathrm{C}$ & 10.68 & 5.87 \\
\hline Platichthys flesus & European flounder & Target & ME-D & 7.12 & 13.25 \\
\hline Crangon crangon & Brown shrimp & Target & ME-D & 2.26 & 4.55 \\
\hline Chelon labrosus & Thicklip grey mullet & Target & ME-O & 0.85 & 0.82 \\
\hline Mugil cephalus & Flathead grey mullet & Target & ME-O & 0.02 & 0.05 \\
\hline Atherina hepsetus & Mediterranean sand smelt & Target & MS & 0.003 & 0.01 \\
\hline Chelon ramada & & Accessory & ME-D & 18.04 & 14.70 \\
\hline Solea solea & & Accessory & ME-O & 8.20 & 10.50 \\
\hline Chelon saliens & & Accessory & ME-D & 6.58 & 5.40 \\
\hline Sparus aurata & & Accessory & ME-D & 4.67 & 4.25 \\
\hline Gobius niger & & Accessory & ES & 3.02 & 2.63 \\
\hline Dicentrarchus labrax & & Accessory & ME-O & 2.95 & 3.83 \\
\hline Mullus surmuletus & & Accessory & ME-O & 2.08 & 4.26 \\
\hline Paeneus keraturus & & Accessory & MS & 0.96 & 1.09 \\
\hline Gobius paganellus & & Accessory & ES & 0.33 & 0.31 \\
\hline Pomatoschistus minutus & & Accessory & ME-O & 0.08 & 0.12 \\
\hline Lithognathus mormyrus & & Accessory & MS & 0.04 & 0.10 \\
\hline Gobius cobitis & & Accessory & MS & 0.01 & 0.02 \\
\hline Chelidonichthys lucerna & & Accessory & ME-O & 0.01 & 0.02 \\
\hline Aphanius fasciatus & & Discard & ESs & 6.05 & 15.44 \\
\hline Engraulis encrasicolus & & Discard & ME-O & 5.38 & 10.62 \\
\hline Belone belone & & Discard & ME-O & 4.61 & 5.94 \\
\hline Sprattus sprattus & & Discard & ME-O & 3.71 & 7.27 \\
\hline Salaria pavo & & Discard & ES & 2.77 & 1.43 \\
\hline Sardina pilchardus & & Discard & ME-O & 0.87 & 1.07 \\
\hline Conger conger & & Discard & MS & 0.54 & 0.97 \\
\hline Pomatomus saltatrix & & Discard & MS & 0.47 & 0.99 \\
\hline Knipowitschia panizzae & & Discard & ESs & 0.31 & 0.37 \\
\hline Hippocampus guttulatus & & Discard & ES & 0.25 & 0.18 \\
\hline Syngnathus typhle & & Discard & ES & 0.14 & 0.12 \\
\hline Alosa fallax & & Discard & A & 0.13 & 0.17 \\
\hline Pomatoschistus marmoratus & & Discard & ES & 0.08 & 0.12 \\
\hline Sciaena umbra & & Discard & MS & 0.07 & 0.13 \\
\hline Syngnathus tenuirostris & & Discard & MS & 0.06 & 0.11 \\
\hline Sepiola rondeletii & & Discard & MS & 0.06 & 0.04 \\
\hline Syngnathus abaster & & Discard & ESs & 0.05 & 0.03 \\
\hline Trachurus trachurus & & Discard & MS & 0.05 & 0.05 \\
\hline Syngnathus acus & & Discard & MS & 0.04 & 0.09 \\
\hline Symphodus melops & & Discard & MS & 0.03 & 0.05 \\
\hline
\end{tabular}


Table 2 (continued)

\begin{tabular}{|c|c|c|c|c|c|}
\hline Species & Common name & Fishery category & $\begin{array}{l}\text { Estuarine use } \\
\text { category }\end{array}$ & $\begin{array}{l}\text { Average cpue (g } \\
\text { trap }^{-1} \text { day }^{-1} \text { ) }\end{array}$ & sd \\
\hline Diplodus vulgaris & & Discard & MS & 0.02 & 0.05 \\
\hline Ninnigobius canestrini & & Discard & ESs & 0.02 & 0.05 \\
\hline Parablennius sanguinolentus & & Discard & MS & 0.01 & 0.03 \\
\hline Symphodus roissali & & Discard & MS & 0.01 & 0.02 \\
\hline Diplodus annularis & & Discard & MS & 0.01 & 0.01 \\
\hline Zebrus zebrus & & Discard & MS & 0.01 & 0.01 \\
\hline Symphodus cinereus & & Discard & MS & 0.01 & 0.01 \\
\hline Sarpa salpa & & Discard & MS & 0.01 & 0.01 \\
\hline Spicara maena & & Discard & MS & 0.01 & 0.02 \\
\hline Diplodus puntazzo & & Discard & MS & 0.004 & 0.01 \\
\hline Gambusia sp & & Discard & FS & 0.003 & 0.005 \\
\hline Trachinotus ovatus & & Discard & MS & 0.003 & 0.01 \\
\hline Hippocampus hippocampus & & Discard & ES & 0.002 & 0.01 \\
\hline Diplodus sargus & & Discard & MS & 0.002 & 0.01 \\
\hline Symphodus ocellatus & & Discard & MS & 0.002 & 0.01 \\
\hline Boops boops & & Discard & MS & 0.002 & 0.002 \\
\hline Syngnathus taenionotus & & Discard & ES & 0.001 & 0.002 \\
\hline Carcinus aestuarii & Green crab & & ES & 1010.65 & 385.11 \\
\hline
\end{tabular}

$E S$ estuarine resident, $E S$ s solely estuarine resident, $M E-D$ marine migrant estuarine-dependent, $M E-O$ marine migrant estuarine-opportunist, $F S$ freshwater straggler, $M S$ marine straggler

\section{Appendix 2}

Table 3 Average values (and standard errors) of environmental variables and morphological properties for each macroarea. Variation is due to both changes in fishing area locations and temporal variability (see the "Methods" section for details)

\begin{tabular}{|c|c|c|c|c|c|c|c|c|c|c|}
\hline Area & TEMP & SAL & DO & TURB & t-RES & TDN & TDP & CHL-A & GRAIN & ELEV \\
\hline $\mathrm{CH}$ & $17.8(0.2)$ & $30.9(0.1)$ & $83.8(0.3)$ & $5.2(0.2)$ & $18.8(0.01)$ & $0.37(0.005)$ & $0.016(0.0004)$ & $1.72(0.05)$ & $47.03(0.28)$ & $-0.81(0.01)$ \\
\hline $\mathrm{CZ}$ & $17.4(0.2)$ & $29.9(0.2)$ & $84.7(0.3)$ & $8.9(0.3)$ & $15.4(0.16)$ & $0.5(0.008)$ & $0.017(0.0005)$ & $1.9(0.06)$ & $6.98(0.21)$ & $-1.08(0.08)$ \\
\hline LT & $18.5(0.5)$ & $26(0.6)$ & $78.8(1)$ & $8.6(0.3)$ & $21.5(-)$ & $0.6(0.008)$ & $0.026(0.0004)$ & $3.15(0.26)$ & $22.31(-)$ & $-0.19(-)$ \\
\hline PL & $18.9(0.2)$ & $31.3(0.1)$ & $99(1.1)$ & $5.7(0.2)$ & $16.5(0.05)$ & $0.44(0.01)$ & $0.033(0.0012)$ & $2.29(0.13)$ & $33.7(4.22)$ & $-1.64(0.05)$ \\
\hline PO & $19.5(0.3)$ & $31.8(0.1)$ & $100.7(0.6)$ & $9.5(0.3)$ & $8.4(0.05)$ & $0.25(0.006)$ & $0.013(0.0004)$ & $1(0.03)$ & $25.47(0.6)$ & $-1.96(0.16)$ \\
\hline SG & $16.9(0.4)$ & $29(0.2)$ & $89.8(1.3)$ & $25.6(1.5)$ & $15.1(0.03)$ & $0.46(0.017)$ & $0.02(0.0009)$ & $2.37(0.31)$ & $6.92(1.25)$ & $-0.83(0)$ \\
\hline
\end{tabular}

Macroareas are abbreviated as follows: $C H$ Chioggia, $C Z$ Ca' Zane, $L T$ Lago dei Teneri, $P L$ Ponte della Libertà, $P O$ Poveglia, $S G$ San Giuliano. Variables are abbreviated as follows: TEMP temperature $\left({ }^{\circ} \mathrm{C}\right), S A L$ salinity, $D O$ dissolved oxygen (saturation \%), TURB turbidity (FNU), $t-R E S$ water residence times (days), TDN total dissolved nitrogen $\left(\mu \mathrm{g} \mathrm{L}^{-1}\right), T D P$ total dissolved phosphorus $\left(\mu \mathrm{g} \mathrm{L}^{-1}\right), C H L-A$ chlorophyll-a $\left(\mu \mathrm{g} \mathrm{L} \mathrm{L}^{-1}\right)$, GRAIN sediment gain size (\% of sand particles), ELEV bottom elevation (m) 


\section{References}

Amara, R., T. Meziane, C. Gilliers, G. Hermel, and P. Laffargue. 2007. Growth and condition indices in juvenile sole Solea solea measured to assess the quality of essential fish habitat. Marine Ecology Progress Series 351: 201-208. https://doi.org/10.3354/ meps07154.

Amorim, E., S. Ramos, M. Elliott, and A.A. Bordalo. 2018. Dynamic habitat use of an estuarine nursery seascape: Ontogenetic shifts in habitat suitability of the European flounder (Platichthys flesus). Journal of Experimental Marine Biology and Ecology 506: 49-60. https://doi.org/10.1016/j.jembe.2018.05.011.

Andolina, C., P. Franzoi, A.L. Jackson, A. Mazzola, and S. Vizzini. 2020. Vegetated habitats trophically support early development stages of a marine migrant fish in a coastal lagoon. Estuaries and Coasts 43: 424-437. https://doi.org/10.1007/ s12237-019-00683-2.

Ardizzone, G.D., S. Cataudella, and R. Rossi. 1988. Management of coastal lagoon fisheries and aquaculture in Italy. AO Fisheries Technical Paper 293: 1-103.

Béné, C. 2011. 12.08 The forgotten service: Food as an ecosystem service from estuarine and coastal zones Treatise on Estuarine and Coastal Science. Vol. 12. Elsevier Inc. https://doi.org/10. 1016/B978-0-12-374711-2.01208-0.

Betzabeth, P.J.E., and L.C.M. de los Ángeles. 2017. Spatial diversity of a coastal seascape: Characterization analysis and application for conservation. Ocean \& Coastal Management 136: 185-195. https://doi.org/10.1016/j.ocecoaman.2016.12.002.

Blaber, S.J.M., and T.G. Blaber. 1980. Factors affecting the distribution of juvenile estuarine and inshore fish. Journal of Fish Biology 17: 143-162. https://doi.org/10.1111/j.1095-8649.1980.tb02749.x.

Boström, C., S.J. Pittman, C. Simenstad, and R.T. Kneib. 2011. Seascape ecology of coastal biogenic habitats: Advances gaps and challenges. Marine Ecology Progress Series 427: 191-217. https://doi.org/10.3354/meps09051.

Breber, P., R. Povilanskas, and A. Armaitiene. 2008. Recent evolution of fishery and land reclamation in Curonian and Lesina lagoons. Hydrobiologia 611: 105-114. https://doi.org/10.1007/ s10750-008-9453-6.

Brooks, M.E., K. Kristensen, K.J. van Benthem, A. Magnusson, C.W. Berg, A. Nielsen, H.J. Skaug, M. Maechler, and B.M. Bolker. 2017. glmmTMB balances speed and flexibility among packages for zero-inflated generalized linear mixed modeling. The $R$ Journal 9: 378-400.

Burnham, K.P., and D.R. Anderson. 2002. Model selection and multimodel inference: A practical information-theoretic approach, 2nd ed. Berlin: Springer-Verlag.

Cataudella, S., D. Crosetti, and F. Massa. 2015. Mediterranean coastal lagoons: Sustainable management and interactions among aquaculture, capture fisheries and the environment. Studies and reviews - General Fisheries Commission for the Mediterranean.

Cataudella, S., and P. Ferlin. 1984. Aspects de basse tecnologie dans l'amenagement des ressources piscicoles et le developpement de l'aquaculture dans les lagunes. Study. Review. GFCM/Etud. Review. CGPM2: 567-591.

Cavraro, F., N. Bettoso, M. Zucchetta, A. D'Aietti, L. Faresi, and P. Franzoi. 2019. Body condition in fish as a tool to detect the effects of anthropogenic pressures in transitional waters. Aquatic Ecology 53: 21-35. https://doi.org/10.1007/s10452-018-09670-4.

Cavraro, F., M. Zucchetta, S. Malavasi, and P. Franzoi. 2017. Small creeks in a big lagoon: The importance of marginal habitats for fish populations. Ecological Engineering 99: 228-237. https:// doi.org/10.1016/j.ecoleng.2016.11.045.

Chauvet, C. 1988. Manuel sur l'aménagement des pêches dans lagunes côtieres: la bordigue méditerranéenee.
Crespi, V. 2002. Recent evolution of the fishing exploitation in the Thau lagoon, France. Fisheries Management and Ecology 9: 19-29. https://doi.org/10.1046/j.1365-2400.2002.00275.x.

Cucco, A., G. Umgiesser, C. Ferrarin, A. Perilli, D. Melaku Canu, and C. Solidoro. 2009. Eulerian and lagrangian transport time scales of a tidal active coastal basin. Ecological Modelling 220: 913-922. https://doi.org/10.1016/j.ecolmodel.2009.01.008.

Curiel, D., F. Scarton, A. Rismondo, and M. Marzocchi. 2005. Pilot transplanting project of Cymodocea nodosa and Zostera marina in the lagoon of Venice: Results and perspectives. Bollettino Del Museo Civico Di Storia Naturale Di Venezia 56: 25-40.

Elliott, M., and K.L. Hemingway. 2002. Fishes in estuaries. Oxford: Blackwell Science.

Engelhard, S.L., C.M. Huijbers, B. Stewart-Koster, A.D. Olds, T.A. Schlacher, and R.M. Connolly. 2016. Prioritizing seascape connectivity in conservation using network analysis. Journal of Applied Ecology 54: 1130-1141. https://doi.org/10.1111/1365-2664.12824.

Facca, C., A. Bonometto, R. Boscolo, A. Buosi, M. Parravicini, A. Siega, V. Volpe, and A. Sfriso. 2014. Coastal lagoon recovery by seagrass restoration. A new strategic approach to meet HD \& WFD objectives. In Proceedings of the 9th European Conference on Ecological Restoration. Oulu, Finland, 3-8 August 2014.

Feola, A., A. Bonometto, E. Ponis, F. Cacciatore, F. Oselladore, B. Matticchio, D. Canesso, et al. 2018. LIFE LAGOON REFRESH. Ecological restoration in Venice Lagoon (Italy): Concrete actions supported by numerical modeling and stakeholder involvement. In Citizen Observatories for Natural Hazards and Water Management - 2nd International Conference. Venice, 27-30 November. http://www.lifelagoonrefresh.eu/file/pubblicazioni/COWM 2018_Extendedabstract.pdf.

Franco, A., R. Fiorin, M. Zucchetta, P. Torricelli, and P. Franzoi. 2010. Flounder growth and production as indicators of the nursery value of marsh habitats in a Mediterranean lagoon. Journal of Sea Research 64: 457-464. https://doi.org/10.1016/j.seares.2010. 01.006 .

Franco, A., P. Franzoi, S. Malavasi, F. Riccato, P. Torricelli, and D. Mainardi. 2006. Use of shallow water habitats by fish assemblages in a Mediterranean coastal lagoon. Estuarine Coastal and Shelf Science 66: 67-83. https://doi.org/10.1016/j.ecss.2005.07.020.

Franco, A., P. Franzoi, and P. Torricelli. 2008. Structure and functioning of Mediterranean lagoon fish assemblages: A key for the identification of water body types. Estuarine Coastal and Shelf Science 79: 549-558. https://doi.org/10.1016/j.ecss.2008.05.011.

Franco, A., S. Malavasi, F. Pranovi, P. Franzoi, and P. Torricelli. 2012. Age and reproductive investment in grass goby females in the Venice lagoon. Environmental Biology of Fishes 93: 419-425. https://doi.org/10.1007/s10641-011-9931-y.

Franco, A., F. Riccato, P. Torricelli, and P. Franzoi. 2009. Fish assemblage response to environmental pressures in the Venice lagoon. Transitional Waters Bulletin 3: 29-44. https://doi.org/10.1285/ i1825229Xv3n1p29.

Franzoi, P., A. Franco, and P. Torricelli. 2010. Fish assemblage diversity and dynamics in the Venice lagoon. Rendiconti Lincei 21: 269-281. https://doi.org/10.1007/s12210-010-0079-z.

Gandolfi, G., S. Zerunian, P. Torricelli, and A. Marconato. 1991. I pesci delle acque interne italiane. Roma: Istituto Poligrafico e Zecca dello Stato.

Georgalas, V., S. Malavasi, P. Franzoi, and P. Torricelli. 2007. Swimming activity and feeding behaviour of larval European sea bass (Dicentrarchus labrax L): Effects of ontogeny and increasing food density. Aquaculture 264: 418-427. https://doi.org/10. 1016/j.aquaculture.2006.09.035.

Gomez, S., J. Lloret, M. Demestre, and V. Riera. 2006. The decline of the artisanal fisheries in Mediterranean coastal areas: The case of Cap de Creus (Cape Creus). Coastal Management 34: 217-232. 
Granzotto, A., P. Franzoi, A. Longo, F. Pranovi, and P. Torricelli. 2001. La pesca nella Laguna di Venezia: un percorso di sostenibilità nel recupero delle tradizioni. Lo stato dell'arte. Rapporto sullo sviluppo sostenibile. Fondazione Enrico Mattei.

Granzotto, A., S. Libralato, F. Pranovi, S. Raichevich, and O. Giovanardi. 2004. Comparison between artisanal and industrial fisheries using ecosystem indicators. Chemistry and Ecology 20: S43-449.

Grati, F., G. Fabi, G. Scarcella, S. Guicciardi, P. Penna, M. Scanu, S. Leoni, et al. 2018. Artificial spawning substrates and participatory research to foster cuttlefish stock recovery: A pilot study in the Adriatic Sea. PLoS ONE 13: 1-14. https://doi.org/10.1371/ journal.pone.0205877.

Guerra, A. 2006. Ecology of Sepia officinalis. Vie Milieu 56: 97-107.

Guerra, A., J. Hernández-Urcera, M.E. Garci, M. Sestelo, M. Regueira, M. Gilcoto, and Á.F. González. 2016. Spawning habitat selection by the common cuttlefish Sepia officinalis in the Cíes Islands (Northwest Spain). Fisheries Research 183: 44-54. https://doi. org/10.1016/j.fishres.2016.04.023.

Hampel, H., A. Cattrijsse, and M. Vincx. 2003. Tidal, diel and semilunar changes in the faunal assemblage of an intertidal salt marsh creek. Estuarine Coastal and Shelf Science 56: 795-805. https:// doi.org/10.1016/S0272-7714(02)00296-2.

Harrison, T.D., and A.K. Whitfield. 2006. Temperature and salinity as primary determinants influencing the biogeography of fishes in South African estuaries. Estuarine Coastal and Shelf Science 66: 335-345.

Henderson, P.A., R.H.A. Holmes, and R.N. Bamber.1988. Size-selective overwintering mortality in the sand smelt, Atherina boyeriRisso, and its role in population regulation. Journal of Fish Biology33. https://doi.org/10.1111/j.1095-8649.1988.tb05465.x

Irlandi, E.A., and M.K. Crawford. 1997. Habitat linkages: The effect of intertidal saltmarshes and adjacent subtidal habitats on abundance movement and growth of an estuarine fish. Oecologia 110: 222-230. https://doi.org/10.1007/s004420050154.

Jones, H.P. 2013. Impact of ecological restoration on ecosystem services. Encyclopedia of biodiversity: Second Edition. Vol. 4. Elsevier Ltd. https://doi.org/10.1016/B978-0-12-384719-5.00326-9.

Kapetsky, J.M., and G. Lasserre. 1984. Management of coastal lagoon fisheries. Edited by J.M. Kapetsky and G. Lasserre. Rome: FAO studies and reviews, GFCM 61. FAO.

Kara, M.H., and J.P. Quignard. 2019. Fishes in lagoons and estuaries in the Mediterranean 2: Sedentary fish. John Wiley \& Sons Ltd.

Koutrakis, E.T., N.I. Kamidis, and I.D. Leonardos. 2004. Age, growth and mortality of a semi-isolated lagoon population of sand smelt, Atherina boyeri (Risso, 1810) (Pisces: Atherinidae) in an estuarine system of northern Greece. Journal of Applied Ichthyology 20: 382-388. https://doi.org/10.1111/j.1439-0426.2004.00583.x.

De la Torre-Castro, M., G. Di Carlo, and N.S. Jiddawi. 2014. Seagrass importance for a small-scale fishery in the tropics: The need for seascape management. Marine Pollution Bulletin 83: 398-407. https://doi.org/10.1016/j.marpolbul.2014.03.034.

Libralato, S., F. Pranovi, S. Raicevich, F. Da Ponte, O. Giovanardi, R. Pastres, P. Torricelli, and D. Mainardi. 2004. Ecological stages of the Venice Lagoon analysed using landing time series data. Journal of Marine Systems 51: 331-344. https://doi.org/10.1016/j. jmarsys.2004.05.020.

Maes, J., S. Damme, P. Meire, and F. Ollevier. 2004. Statistical modeling of seasonal and environmental influences on the population dynamics of an estuarine fish community. Marine Biology 145: 1033-1042. https://doi.org/10.1007/s00227-004-1394-7.

Magistrato alle Acque di Venezia (ora Provveditorato Interregionale alle OO. PP. del Veneto- Trentino Alto Adige - Friuli Venezia Giulia). 2002. Carta Tecnica della laguna di Venezia. Prodotto dal Concessionario, Consorzio Venezia Nuova.

Magistrato alle Acque di Venezia (ora Provveditorato Interregionale alle OO. PP. del Veneto- Trentino Alto Adige - Friuli Venezia Giulia - SAMA. 2013. Dati rete di monitoraggio SAMANET.
Magistrato alle Acque di Venezia (ora Provveditorato Interregionale alle OO. PP. del Veneto - Trentino Alto Adige - Friuli Venezia Giulia) - Selc. 2005. Studio B.12.3/III. La funzionalità dell'ambiente lagunare attraverso rilievi delle risorse alieutiche, dell'avifauna e dell'ittiofauna. Erodibilità del fondale e fattori di disturbo: Rilievi dell'erodibilità del fondale. Rapporto intermedio.

Magistrato alle Acque di Venezia (ora Provveditorato Interregionale alle OO. PP. del Veneto - Trentino Alto Adige - Friuli Venezia Giulia) - Thetis. 2005. Programma generale delle attività di approfondimento del quadro conoscitivo di riferimento per gli interventi ambientali. $2^{\circ}$ stralcio triennale (2003-2006) "Progetto ICSEL". Attività A.

Malavasi, S., A. Franco, R. Fiorin, P. Franzoi, P. Torricelli, and D. Mainardi. 2005. The shallow water gobiid assemblage of the Venice Lagoon: Abundance, seasonal variation and habitat partitioning. Journal of Fish Biology 67: 146-165. https://doi.org/ 10.1111/j.0022-1112.2005.00919.x.

Marshall, S., and M. Elliott. 1998. Environmental influences on the fish assemblage of the Humber Estuary UK. Estuarine Coastal and Shelf Science 46: 175-184. https://doi.org/10.1006/ecss. 1997.0268.

Matozzo, V., A. Boscolo, and M.G. Marin. 2013. Seasonal and genderrelated differences in morphometric features and cellular and biochemical parameters of Carcinus aestuarii from the Lagoon of Venice. Marine Environmental Research 89: 21-28. https:// doi.org/10.1016/j.marenvres.2013.04.007.

McGarigal, K., S.A. Cushman, M.C. Neel, and E. Ene. 2002. FRAGSTATS: Spatial pattern analysis program for categorical maps. Amherst: University of Massachusetts.

Menz, M.H.M., K.W. Dixon, and R.J. Hobbs. 2013. Hurdles and opportunities for landscape-scale restoration. Science 339: 526-527. https://doi.org/10.1126/science.1228334.

Meynecke, J.O., S.Y. Lee, and N.C. Duke. 2008. Linking spatial metrics and fish catch reveals the importance of coastal wetland connectivity to inshore fisheries in Queensland, Australia. Biological Conservation 141: 981-996. https://doi.org/10.1016/j.biocon. 2008.01.018.

Mizerek, T., H.M. Regan, and K.A. Hovel. 2011. Seagrass habitat loss and fragmentation influence management strategies for a blue crab Callinectes sapidus fishery. Marine Ecology Progress Series 427: 247-257. https://doi.org/10.3354/meps09021.

Mohapatra, A., R.K. Mohanty, S.K. Mohanty, K.S. Bhatta, and N.R. Das. 2007. Fisheries enhancement and biodiversity assessment of fish, prawn and mud crab in Chilika lagoon through hydrological intervention. Wetlands Ecology and Management 15: 229-251. https://doi.org/10.1007/s11273-006-9025-3.

Molinaroli, E., S. Guerzoni, A. Sarretta, A. Cucco, and G. Umgiesser. 2007. Links between hydrology and sedimentology in the Lagoon of Venice Italy. Journal of Marine Systems 68: 303-317. https://doi.org/10.1016/j.jmarsys.2006.12.003.

Mumby, P.J. 2006. Connectivity of reef fish between mangroves and coral reefs: Algorithms for the design of marine reserves at seascape scales. Biological Conservation 128: 215-222. https://doi. org/10.1016/j.biocon.2005.09.042.

Pastres, R., C. Solidoro, S. Ciavatta, A. Petrizzo, and G. Cossarini. 2004. Long-term changes of inorganic nutrients in the Lagoon of Venice (Italy). Journal of Marine Systems 51: 179-189. https:// doi.org/10.1016/j.jmarsys.2004.05.011.

Pérez-Ruzafa, A., and C. Marcos. 2012. Fisheries in coastal lagoons: An assumed but poorly researched aspect of the ecology and functioning of coastal lagoons. Estuarine Coastal and Shelf Science 110: 15-31. https://doi.org/10.1016/j.ecss.2012.05.025.

Pérez-Ruzafa, A., C. Marcos, and I.M. Pérez-Ruzafa. 2011. Mediterranean coastal lagoons in an ecosystem and aquatic resources management context. Physics and Chemistry of the Earth 36: 160-166. https://doi.org/10.1016/j.pce.2010.04.013. 
Pérez-Ruzafa, A., Ma Carmen Mompeán, and C. Marcos. 2007. Hydrographic geomorphologic and fish assemblage relationships in coastal lagoons. Hydrobiologia 577: 107-125. https://doi.org/ 10.1007/s10750-006-0421-8.

Perring, M.P., R.J. Standish, J.N. Price, M.D. Craig, T.E. Erickson, K.X. Ruthrof, A.S. Whiteley, L.E. Valentine, and R.J. Hobbs. 2015. Advances in restoration ecology: Rising to the challenges of the coming decades. Ecosphere 6:art131. https://doi.org/10. 1890/ES15-00121.1.

Piazza, B.P., and M.K. La Peyre. 2010. Using Gambusia affinis growth and condition to assess estuarine habitat quality: A comparison of indices. Marine Ecology Progress Series 412: 231-245. https://doi.org/10.3354/meps08686.

Pihl, L., A. Cattrijsse, I. Codling, S. Mathieson, D.S. Mclusky, and C. Roberts. 2002. Habitat use by fishes in estuaries and other brackish areas. In Fishes in estuaries, ed. M. Elliott and K. L. Hemingway, 1992:10-53. Blackwell Publishing Ltd.

Pita, C., S. Gamito, and K. Erzini. 2002. Feeding habits of the gilthead seabream (Sparus aurata) from the Ria Formosa (southern Portugal) as compared to the back seabream (Spondyliosoma cantharus) and the annular seabream (Diplodus annularis). Journal of Applied Ichthyology 18: 81-86. https://doi.org/10.1046/j. 1439-0426.2002.00336.x.

Pittman, S.J., C. Caldow, S.D. Hile, and M.E. Monaco. 2007. Using seascape types to explain the spatial patterns of fish in the mangroves of SW Puerto Rico. Marine Ecology Progress Series 348: 273-284. https://doi.org/10.3354/meps07052.

Potter, I.C., J.R. Tweedley, M. Elliott, and A.K. Whitfield. 2013. The ways in which fish use estuaries: A refinement and expansion of the guild approach. Fish and Fisheries 16: 230-239. https://doi. org/10.1111/faf.12050.

Pranovi, F., A. Caccin, P. Franzoi, S. Malavasi, M. Zucchetta, and P. Torricelli. 2013. Vulnerability of artisanal fisheries to climate change in the Venice Lagoon. Journal of Fish Biology 83: 847864. https://doi.org/10.1111/jfb.12124.

Provincia di Venezia, ed. 2000. Piano per la gestione delle risorse alieutiche delle lagune della provincia di Venezia. Provincia di Venezia. Benevento: Sannioprint.

Provincia di Venezia. 2009. Piano per la gestione delle risorse alieutiche delle lagune di Venezia e Caorle. Edited by P. Torricelli, V. Boatto, P. Franzoi, P. Pellizzato, and S. Silvestri. Dosson di Casier, TV: Arti Grafiche Zotelli.

Provincia di Venezia. 2015. Piano per la gestione delle risorse alieutiche delle lagune di Venezia e Caorle.

Quignard, J.P. 1984. Les caracteristiques biologiques et environmentales des lagunes en tant que base biologique de l'amenagement des pecheries. In Management of coastal lagoon fisheries, ed. J. M. Kapetsky and G. Lasserre, 3-38. Rome: FAO Studies and Reviews 61

R Core Team. 2014. R: A language and environment for statistical computing. R Foundation for Statistical Computing, Vienna, Austria. R Foundation for Statistical Computing, Vienna, Austria.

Reese, M.M., G.W. Stunz, and A.M. Bushon. 2008. Recruitment of estuarine-dependent nekton through a new tidal inlet: The opening of Packery Channel in Corpus Christi TX USA. Estuaries and Coasts 31: 1143-1157. https://doi.org/10.1007/ s12237-008-9096-x.

MS Romdhane C Fassatoui M Shaiek ABR Jenhani T Changeux 2019 Mugilids fisheries of Tunisian coasts and lagoons Aquatic Living Resources 32 https://doi.org/10.1051/alr/2019005

Rountree, R.A., and K.W. Able. 2007. Spatial and temporal habitat use patterns for salt marsh nekton: Implications for ecological functions. Aquatic Ecology 41: 25-45. https://doi.org/10.1007/ s10452-006-9052-4.

Rova, S., F. Pranovi, and F. Müller. 2015. Provision of ecosystem services in the lagoon of Venice (Italy): An initial spatial assessment. Ecohydrology \& Hydrobiology 15: 13-25. https:// doi.org/10.1016/j.ecohyd.2014.12.001.

Rozas, L.P., P. Caldwell, and T.J. Minello. 2005. The fishery value of salt marsh restoration projects. Journal of Coastal Research 37-50.

Sarretta, A., S. Pillon, E. Molinaroli, S. Guerzoni, and G. Fontolan. 2010. Sediment budget in the Lagoon of Venice Italy. Continental Shelf Research 30: 934-949. https://doi.org/10.1016/j.csr.2009.07.002.

Scapin, L., S. Redolfi Bristol, F. Cavraro, M. Zucchetta, and P. Franzoi. 2019a. Fish fauna in the Venice lagoon: Updating the species list and reviewing the functional classification. Italian Journal of Freshwater Ichthyology 5: 271-277.

Scapin, L., M. Zucchetta, A. Bonometto, A. Feola, R. Boscolo Brusà, A. Sfriso, and P. Franzoi. 2019b. Expected shifts in nekton community following salinity reduction: Insights into restoration and management of transitional water habitats. Water 11: 1354. https://doi.org/10.3390/w11071354.

Scapin, L., M. Zucchetta, A. Sfriso, and P. Franzoi. 2018. Local habitat and seascape structure influence seagrass fish assemblages in the Venice lagoon: The value of conservation at multiple spatial scales. Estuaries and Coasts 41: 2410. https://doi.org/10.1007/ s12237-018-0434-3.

Scapin, L., M. Zucchetta, A. Sfriso, and P. Franzoi. 2019c. Predicting the response of nekton assemblages to seagrass transplantations in the Venice lagoon: An approach to assess ecological restoration. Aquatic Conservation: Marine and Freshwater Ecosystems Marine and Freshwater Ecosystems 26: 849-864. https://doi.org/ 10.1002/aqc.3071.

Solidoro, C., V. Bandelj, F.A. Bernardi, E. Camatti, S. Ciavatta, G. Cossarini, R. Pastres, et al. 2010. Response of the Venice lagoon ecosystem to natural and anthropogenic pressures over the last 50 years. In Coastal lagoons: Critical habitats of environmental change, ed. M.J. Kennish and H.W. Paerl, 483-512. Boca Raton, FL: CRC Marine Science.

Solidoro, C., D. Melaku canu, A. Cucco, and G. Umgiesser. 2004. A partition of the Venice Lagoon based on physical properties and analysis of general circulation. Journal of Marine Systems 51: 147-160.

Stamoulis, K.A., J.M.S. Delevaux, I.D. Williams, M. Poti, J. Lecky, B. Costa, M.S. Kendall, et al. 2018. Seascape models reveal places to focus coastal fisheries management. Ecological Applications 28: 910-925. https://doi.org/10.1002/eap.1696.

Staveley, Thomas A.B.., Diana Perry, Regina Lindborg, and Martin Gullström. 2017. Seascape structure and complexity influence temperate seagrass fish assemblage composition. Ecography 40: 936-946. https://doi.org/10.1111/ecog.02745.

Suding, K.N. 2011. Toward an era of restoration in ecology: Successes, failures, and opportunities ahead. In Annual review of ecology, evolution, and systematics, Vol. 42, ed. D. J. Futuyma, H. B. Shaffer, and D. Sim- berloff, 465-487. Annual Reviews, Palo Alto, CA, USA. https://doi.org/10.1146/annurevecolsys-102710-145115.

Tancioni, L., S. Mariani, A. Maccaroni, A. Mariani, F. Massa, M. Scardi, and S. Cataudella. 2003. Locality-specific variation in the feeding of Sparus aurata L.: Evidence from two Mediterranean lagoon systems. Estuarine, Coastal and Shelf Science 57: 469-474. https://doi.org/10.1016/S0272-7714(02)00376-1.

Thetis S.p.A. (Ed.). 2010. Stato dell'ecosistema lagunare veneziano. Venezia: Marsilio.

Tsihrintzis, V.A., G.K. Sylaios, M. Sidiropoulou, and E.T. Koutrakis. 2007. Hydrodynamic modeling and management alternatives in a Mediterranean fishery exploited coastal lagoon. Aquacultural Engineering 36: 310-324. https://doi.org/10.1016/j.aquaeng.2007.01.007.

Umgiesser, G., C. Ferrarin, A. Cucco, F. de Pascalis, D. Bellafiore, G. Michol, and B. Marco. 2014. Comparative hydrodinamics of 10 Mediterranean lagoons by means of numerica modeling. Journal of Geophysical Research: Oceans 119: 2212-2226. https://doi. org/10.1002/2013JC009512. 
Umgiesser, G., D. Melaku canu, A. Cucco, and C. Solidoro. 2004. A finite element model for the Venice Lagoon. Development set up calibration and validation. Journal of Marine Systems 51: 123-145. https://doi.org/10.1016/j.jmarsys.2004.05.009.

Warton, D.I. 2008. Raw data graphing: An informative but underutilized tool for the analysis of multivariate abundances. Austral Ecology 33: 290-300. https://doi.org/10.1111/j.1442-9993.2007. 01816.x.

Warton, D.I., S.D. Foster, G. De'ath, J. Stoklosa, and P.K. Dunstan. 2014. Model-based thinking for community ecology. Plant Ecology 216 (5): 669-682. https://doi.org/10.1007/s11258-014-0366-3.

Whitfield, A.K. 2017. The role of seagrass meadows, mangrove forests, salt marshes and reed beds as nursery areas and food sources for fishes in estuaries. Reviews in Fish Biology and Fisheries 27: 75-110. https://doi.org/10.1007/s11160-016-9454-x.

Whitfield, A.K., S.J.M. Blaber, and D.P. Cyrus. 1981. Salinity ranges of some southern African fish species occurring in estuaries. African Zoology 16: 151-155.

Wickham, H. 2016. ggplot2: Elegant graphics for data analysis. New York: Springer-Verlag.
Zucchetta, M., G. Cipolato, F. Pranovi, P. Antonetti, P. Torricelli, P. Franzoi, and S. Malavasi. 2012. The relationships between temperature changes and reproductive investment in a Mediterranean goby: Insights for the assessment of climate change effects. Estuarine Coastal and Shelf Science 101: 15-23. https://doi.org/ 10.1016/j.ecss.2012.01.009.

Zucchetta, M., A. Franco, P. Torricelli, and P. Franzoi. 2010. Habitat distribution model for European flounder juveniles in the Venice lagoon. Journal of Sea Research 64: 133-144.

Zucchetta, M., L. Scapin, F. Cavraro, F. Pranovi, A. Franco, and P. Franzoi. 2016. Can the effects of anthropogenic pressures and environmental variability on nekton fauna be detected in fishery data Insights from the monitoring of the artisanal fishery within the Venice lagoon. Estuaries and Coasts 39: 1164-1182. https:// doi.org/10.1007/s12237-015-0064-y.

Zuur, A., E.N. Ieno, and G.M. Smith. 2007. Analyzing ecological data. Springer.

Zuur, A., E.N. Ieno, N. Walker, A.A. Saveliev, and G.M. Smith. 2009. Mixed effects models and extensions in ecology with R. New York: Springer-Verlag. https://doi.org/10.1007/978-0-387-87458-6. 